DOI: 10.32089/WBH.PHW.2021.1(275).0003

orcid.org/0000-0003-2766-845X

\author{
DANiel Koreś
}

Oddziałowe Biuro Badań Historycznych IPN we Wrocławiu

\title{
U źródell afery TUN. \\ Generał Stanisław Tatar, rozpad Komitetu Trzech i przekazanie komunistycznemu wywiadowi wojskowemu funduszu „Drawa” 1947-1949
}

\begin{abstract}
The article is a synthesis of the activities of the members of the self-proclaimed Committee of Three (Brig. Gen. Stanisław Tatar and his associates - Col. Stanisław Nowicki and Lt. Col. Marian Utnik) from 1947-1949 - until their arrest by the communist security service in November 1949. Based on archival sources, it presents not only the moral decay of three high-ranking and positioned officers of the Polish Army and the Polish Armed Forces, but also a much more painful study of their agent activities and mutual deliberation inspired by the II Department of the General Staff of the Polish People's Army.

W końcu maja 1947 r. gen. bryg. Stanisław Tatar i jego wspólnicy płk dypl. Stanisław Nowicki oraz ppłk dypl. Marian Utnik - zdecydowali się jawnie na współpracę z komunistycznym wywiadem wojskowym. Pod płaszczykiem szczytnych celów, za zdefraudowane pieniądze $\mathrm{z}$ funduszu „Drawa” oraz złoto z Funduszu Obrony Narodowej, należące do polskiego rządu na emigracji, kupowali sobie faktycznie lepszą przyszłość w Polsce Ludowej. ${ }^{1}$ Tak przynajmniej sądzili, gdyż nieodległa przyszłość brutalnie

Artykuł ten jest bezpośrednią kontynuacją studium opublikowanego w 2020 r., zob. Daniel Koreś, „Zanim wybuchła afera TUN. Generał Stanisław Tatar, Komitet Trzech, fundusz «Drawa» i operacja «Brzoza» 1944-1947," Pamięć i Sprawiedliwość, nr 2 (36) (2020):
\end{abstract}


zweryfikowała ich przypuszczenia. Niniejsza synteza działalności członków samozwańczego Komitetu Trzech z lat 1947-1949 - do momentu ich aresztowania przez komunistyczną służbę bezpieczeństwa - jest zapisem nie tylko upadku moralnego trzech wysokich stopniem i stanowiskiem oficerów Wojska Polskiego i Polskich Sił Zbrojnych na Zachodzie (PSZ), lecz także o wiele bardziej bolesnym studium ich wzajemnego delatorstwa na rzecz Oddziału II Sztabu Generalnego ludowego Wojska Polskiego (SG IWP).

Działalność samozwańczego Komitetu Trzech, zainicjowana przez zastępcę szefa Sztabu Naczelnego Wodza (SNW) ds. Krajowych gen. bryg. Tatara ps. „Tabor”, na przełomie listopada i grudnia 1944 r., ${ }^{2}$ doprowadziła w przeciągu następnego roku do przejęcia funduszy dotąd pozostających w gestii Oddziału VI SNW, przy zaskakującej bierności kierownictwa Polskich Sił Zbrojnych. ${ }^{3}$ Pomimo tego, że w 1946 r. Tatar musiał pogodzić się ze stratą blisko $2 / 3$ funduszu dolarowego, który przejęło dowództwo 2 Korpusu Polskiego ${ }^{4}$ (w Rzymie) i szef Sztabu Głównego PSZ wraz z nieuznawanym już Rządem $\mathrm{RP}^{5}$ (depozyty na terenie Niemiec), to i tak udało mu się zabezpieczyć na terenie Francji, Wlk. Brytanii i w innych krajach majątek przekraczający znacznie $3 \mathrm{mln}$ dolarów (odpowiadający obecnym 40-45 mln dolarów amerykańskich). ${ }^{6}$ Kwotę tę uzupełniał tzw. złoty skarb Funduszu Obrony Narodowej (FON), który znajdował się w gestii Ministerstwa Obrony Narodowej (MON) i w 1945 r. został lekkomyślnie przekazany przez jego szefa gen. dyw. Mariana Kukiela pod kuratelę Tatara. ${ }^{7}$ Działania Komitetu, noszące wszelkie znamiona defraudacji majątku należącego do Skarbu Państwa, zawsze zmierzały w jednym kierunku: powrotu do Polski i wykorzystania zawłaszczonego majątku w celu zabezpieczenia własnej przyszłości. Oczywiście dążenia te na zewnątrz starannie maskowano troską o odbudowę kraju. Posiadając odpowiednie środki, Tatar i jego wspólnicy stali się atrakcyjnym partnerem - początkowo dla próbującego legalnie zdobyć władzę byłego premiera Stanisława Mikołajczyka i jego

\footnotetext{
409-435, https://doi.org/10.48261/PIS203622. Tam też wymieniona jest literatura przedmiotu. Warto także odnotować inne ujęcie tego zagadnienia: Andrzej Paczkowski, „W pogoni za złotem, czyli operacja TUN," Studia Polityczne 37, nr 1 (2015): 65-91.

2 Koreś, „Zanim,” 410.

3 Ibid., 417, 418.

4 Ibid., 414, 415 .

5 Ibid., 415, 418 i n.

6 Ibid.

7 Ibid., 414.
} 
zaplecza politycznego, ${ }^{8}$ a gdy jego gwiazda zaczęła gasnąć, dla komunistycznego wywiadu wojskowego, który firmował się w tej kwestii jako przedstawicielstwo legalnych władz Polski. ${ }^{9}$ Choć członkowie Komitetu w pierwszym okresie próbowali ostrożnie negocjować z przedstawicielami reżimu warszawskiego, to w miarę upływu czasu dawali się wciągać coraz mocniej $\mathrm{w}$ konszachty z funkcjonariuszami Oddziału II, kierowanego przez sprytnego i bezwzględnego płk./gen. bryg. Wacława Komara. Im bliższe stawały się relacje Tatara, Utnika i Nowickiego z komunistycznym aparatem wywiadowczym i dyplomatycznym, tym bardziej ich pozycja w polskim Londynie stawała się niewygodna. ${ }^{10}$ Była to cyniczna gra Komara - nadzorowanego w tym względzie przez członka sanhedrynu władz komunistycznych, gen. dyw. Mariana Spychalskiego ${ }^{11}$ - zmierzająca ku przejęciu funduszu „Drawa” oraz złota FON. Im większemu ostracyzmowi podlegali członkowie Komitetu wśród polskiego uchodźstwa politycznego i wojskowego, tym bardziej wplątywali się w pajęczą sieć, jaką Komar wokół nich tkał. W 1947 r. Tatar et consortes przekroczyli swój Rubikon, parafując formalną umowę z Polską Ludową o przekazaniu złota, dolarów oraz spieniężenia posiadanych nieruchomości. ${ }^{12}$ Przejęcie złota FON (operacja „Brzoza” ${ }^{13}$ ) miało zainicjować cały proces. Po czerwcu 1947 r., snując nierealne plany swojego urządzenia się w komunistycznej rzeczywistości, członkowie Komitetu zaczęli grzęznąć w konfliktach wewnętrznych, wzajemnej nieufności a wręcz wrogości, co dało pożywkę dla Komara i jego podwładnych oraz możliwość poprowadzenia całej afery tak, żeby doprowadzić ich do ostatecznego upadku. Poniżej znajduje się zapis tego procesu, aż do początku listopada 1949 r., gdy cała trójka została aresztowana.

Wraz z zakończeniem sukcesem operacji „Brzoza” komunistyczny wywiad wojskowy zaczął toczyć z Tatarem, Utnikiem i Nowickim świadomą i cyniczną grę mającą na celu zdobycie środków finansowych będących w gestii Komitetu Trzech. Z jednej strony usypiano czujność Tatara, jak choćby 24 czerwca 1947 r., gdy Komar depeszował do Maksymiliana Chojeckiego ${ }^{14}$, attaché woj-

\footnotetext{
$8 \quad$ Ibid., $415,416$.

9 Ibid., 419, 420, 425 i n.

10 Ibid., 421, 422 i n.

11 Ibid., 420, 428.

12 Ibid., 426, 427.

13 Ibid., 430, 431.

14 Maksymilian Chojecki (ur. 1 I 1899 - zm. 18 VII 1980) - mjr art. WP i płk art. lWP, od 15 X 1945 r. był członkiem Misji Wojskowej w Wlk. Brytanii, potem zastępcą i wreszcie attaché wojskowym w Londynie (od 1 III 1947 r.). Odegrał ważną rolę w przejęciu funduszu „Drawa” oraz w kontaktach z Komitetem Trzech, po wyjeździe z Londynu swojego poprzednika płk. dypl. Józefa Kuropieski. Aresztowany równocześnie z Tatarem, Utnikiem
} 
skowego $\mathrm{w}$ Londynie, z poleceniem uspokojenia go, że ataki prasowe $\mathrm{w}$ prasie krajowej skierowane przeciwko niemu to "posunięcie taktyczne” i nie należy brać ich serio. ${ }^{15} \mathrm{Z}$ drugiej strony obawiano się jego wybuchowego charakteru, który mógł doprowadzić do zerwania współpracy. ${ }^{16}$ Do momentu przejęcia „Drawy” w całym, deklarowanym przez Tatara, wymiarze, obchodzono się z nim niezwykle ostrożnie i delikatnie.

Tatar wyjechał z Londynu do Polski 18 lipca 1947 r. Najpierw odwiedził Paryż, gdzie spędził kilka dni, a 24 lipca wyruszył pociągiem do Warszawy, gdzie dotarł następnego dnia. ${ }^{17} \mathrm{~W}$ Polsce, pierwszy raz od trzech lat, przebywał przez 30 dni i 23 sierpnia odleciał samolotem z Okęcia do Londynu. Funkcjonariusze wywiadu zadbali o to, żeby Tatar odniósł $\mathrm{z}$ wyjazdu tylko korzystne wrażenia - na polecenie gen. Komara jego „opiekunem”, jako oficer do zleceń, został kierownik Sekcji Brytyjskiej w Oddziale II kpt. Tadeusz Marian Gronowicz. ${ }^{18}$ Pierwsze efekty wizyta w kraju przyniosła już w kilka tygodni później - 15 września 1947 r. miała miejsce konferencja w Ambasadzie Polski Ludowej w Londynie, m.in. z udziałem Tatara i inż. Otowskiego, delegata Ministerstwa Przemysłu, w czasie której ustalono szczegóły szeroko zakrojonego planu zakupów na rzecz Polski w krajach zachodnich, oczywiście dzięki funduszowi „Drawa”. Zadecydowano wówczas o otwarciu przy Ambasadzie tzw. biura zakupów Tatara, którym miał kierować Utnik. ${ }^{19}$

i Nowickim 3 XI 1949 r. i po długim śledztwie został skazany na karę śmierci (14 VI 1952 r., podobnie jak Kuropieska), w przeciwieństwie do członków Komitetu Trzech. Wyrok zamieniono na karę pozbawienia wolności, w 1955 r. został zwolniony i następnie zrehabilitowany.

15 Archiwum Instytutu Pamięci Narodowej w Warszawie (dalej: AIPN), Szefostwo Wojskowej Służby Wewnętrznej (dalej: SWSW), 2306/13909/1, Szyfrogram Wacława Komara do Maksymiliana Chojeckiego, nr 25, b.m., 24 VI 1947 r., 235.

16 Chojecki depeszował szefowi wywiadu: „Atakowanie Tatara godzi pośrednio w jego ludzi, którzy pilnują funduszów i majątku, przeważnie na terenie kontynentu. Informowanie ich o właściwym celu ataków jest technicznie nie do wykonania, a może to spowodować niepotrzebne następstwa. Następnie wobec obecnie już wiadomego zgłoszenia u Brytyjczyków na wyjazd do kraju Utnika i Tatara uważam projektowane wiadomości w prasie krajowej za niepożądane"; ibid., Szyfrogram Maksymiliana Chojeckiego do Wacława Komara, nr 49/B.S., b.m., 25 VI 1947 r., 237.

17 Zob. więcej AIPN, Ministerstwo Spraw Wewnętrznych w Warszawie (dalej: MSW), 0192/760/24, cz. 2, Raport z pobytu generała Tatara w Polsce [w 1947 r.], odpis, b.m., b.d., 282-288; zob. także ibid., Raport z podróży gen. Tatara do Krakowa w dniach 6-10 VIII [1947], odpis, Warszawa, 11 VIII 1947 r., 289-292.

18 AIPN, SWSW, 2386/13888, [kpt. Tadeusz M. Gronowicz] Notatka w sprawie pobytu Tatara w Warszawie w 1947 r., b.m., 24 II 1951 r., 164, 165. Oficer ten przygotował notatkę dopiero w niemalże cztery lata później, gdy Tatar już od ponad roku znajdował się w areszcie śledczym Głównego Zarządu Informacji (GZI). Dowodzi to dość nonszalanckiego podejścia Komara do sprawy.

19 Ibid., 2306/13909/1, Pismo płk. Maksymiliana Chojeckiego do gen. Wacława Komara, nr 00630/47, b.m., 18 IX 1947 r., 262. 
Biuro miało przede wszystkim realizować zakupy sprzętu i materiałów wg zapotrzebowania płynącego z Warszawy, a konkretnie z szefostwa wywiadu wojskowego, choć w konsultacji z Ministerstwem Przemysłu. ${ }^{20}$ Ustalono także uruchomienie akcji przerzutu gotówki z „Drawy” - pierwszą transzę w wysokości ok. 200 tys. dolarów miał podjąć w Paryżu, po 28 września 1947 r., Utnik i przewieźć bezpośrednio do Warszawy. Chojecki prosił więc Komara o udzielenie Utnikowi wszelkiej pomocy na paryskim gruncie, zauważył przy tym, że „stosowanie większości przerzutów pieniężnych z Francji będzie korzystne również dla pewnego zamaskowania akcji na tym terenie", mając na myśli Wlk. Brytanię. Z pełną premedytacją pominięto przy akcji zakupowej attaché handlowego ambasady w Londynie, dając Komitetowi Trzech poczucie swobody oraz podnosząc wrażenie wartości ich pracy „dla kraju”. Był to jeden z ważnych elementów gry operacyjnej, jaką wywiad toczył z członkami Komitetu.

W drugiej połowie 1947 r. Tatar, jako lider Komitetu Trzech, zdecydowany był już na pełną współpracę z komunistami. W lipcu tr. Utnik ${ }^{21}$ i Nowicki ${ }^{22}$ (i zapewne także Tatar, choć w jego przypadku nie udało mi się dotąd znaleźć stosownego dokumentu) ostatecznie odmówili wstąpienia do Polskiego Korpusu Przysposobienia i Rozmieszczenia (PKPiR), a żeby nie zostać usuniętymi z terenu Wlk. Brytanii, otrzymali fikcyjne zatrudnienie na terenie Ambasady Polski Ludowej w Londynie oraz paszporty dyplomatyczne ${ }^{23}$,

20 Sprawa zakupów różnych sprzętów, urządzeń precyzyjnych, materiałów, surowców etc., zlecanych Komitetowi przez Warszawę, stanowi odrębny problem, który opiszę w najbliższym czasie w osobnym tekście. Trzeba jednak podkreślić, że zakupy te odbywały się nie tylko ze środków funduszu „Drawa”, lecz także przekazywanych z Narodowego Banku Polskiego via Oddział II SG (ibid., 2306/13910, Pismo płk. Maksymiliana Chojeckiego do gen. Wacława Komara, Nr 0107/48, b.m., 11 III 1948 r., 49). Oznaczało to, że Komitet Trzech (a przede wszystkim oddelegowany do tych spraw Utnik) pełnił także rolę wyspecjalizowanej placówki handlowej, potrafiącej zdobyć niemalże każdy sprzęt - nawet potencjalnie niedostępny dla Polski Ludowej, jak np. brytyjski aparat do mikrofilmowania: „chcę zaznaczyć, że zakupienie go na rynku tutejszym dla nas jest niemożliwe - nabyliśmy go innymi trochę, może skomplikowanymi, metodami”; zob. ibid., List Maksymiliana Chojeckiego do płk. Stanisława Flato, b.m., 18 IX 1947 r., 42, 43.

${ }^{21}$ Utnik już 5 IX 1946 r. przygotował oświadczenie nt. rezygnacji ze wstąpienia do Polskiego Korpusu Przysposobienia i Rozmieszczenia, ale najprawdopodobniej ostatecznie wtedy go nie wysłał. Zob. Centralne Archiwum Wojskowe Wojskowego Biura Historycznego (dalej: CAW-WBH), Oddział VI Sztabu Naczelnego Wodza (dalej: O. VI SNW), II.54.354, Pismo ppłk. dypl. Mariana Utnika do pomocnika zastępcy szefa Sztabu dla Spraw Ogólnych, b.m., 5 IX 1946 r., 39, 40.

22 W końcu lipca 1947 r. procedurę zwolnienia z PSZ kończył Nowicki - Utnik już wcześniej ją wdrożył; Nowicki także został fikcyjnie zatrudniony w ambasadzie w Londynie; AIPN, SWSW, 2306/13909/1, Szyfrogram Maksymiliana Chojeckiego do Wacława Komara, nr 122/B.S., b.m., 30 VII 1947 r., 257.

23 Polecenie wydania całej trójce paszportów dyplomatycznych „na kontynent - by mogli oni odebrać przechowywane tam sumy" po raz pierwszy Komar wydał w połowie maja 
które sankcjonowały ich dalszy pobyt na Wyspach Brytyjskich. ${ }^{24}$ Gra pozorów definitywnie się skończyła. Kolejnym przykładem świadomego odcięcia się od dawnych sojuszników była odmowa udzielenia jakiejkolwiek pomocy Mikołajczykowi, wyrażona przez Utnika, za wiedzą i wolą Tatara, Czesławowi Raczkowskiemu 30 października 1947 r. Raczkowski, były kurier cywilny i skoczek do kraju (w pierwszej ekipie zrzuconej w nocy z 15 na 16 lutego 1941 r.), mąż zaufania Mikołajczyka w Londynie, poprosił Utnika o pomoc w przewiezieniu kwoty 2 tys. funtów szterlingów z Paryża do Londynu. 4 listopada 1947 r. do Utnika miał się także zgłosić „wysłannik Kopańskiego”, który także sondował go w sprawie wsparcia z funduszu „Drawa” sprawy Mikołajczyka - padła kategoryczna odmowa. Jest bardzo prawdopodobne, że obie sytuacje były także próbami Mikołajczyka ominięcia Tatara i dotarcia za jego plecami do Utnika. Jest także możliwe, że Mikołajczyk sondował w ten sposób swojego dawnego sojusznika, który jeszcze rok wcześniej wspierał go finansowo $\mathrm{z}$ funduszu dolarowego.

W początku października 1947 r. Tatar osobiście pojechał do Paryża załatwić transfer pierwszej transzy gotówki dla rządu komunistycznego - pierwotnie miał jechać Utnik (o czym była mowa wyżej), lecz zapewne nie ufając mu, lub $\mathrm{z}$ innego powodu, sam postanowił dopilnować sprawy. To jednak Utnik pojechał wówczas z pieniędzmi do Polski - gdzie przebywał pomiędzy 10 a 18 października 1947 r., a jego oficerem do zleceń był kpt. Tadeusz Przybysz z Oddziału II SG ${ }^{25}$ - w czasie pobytu dwukrotnie rozmawiał z Komarem, który podjął próbę werbunku Utnika jako agenta

1947 r.; ibid., Pismo gen. Wacława Komara do płk. Maksymiliana Chojeckiego, Nr 01290/II, b.m., 14 V 1947 r., 197.

24 Dyskusja na temat sprawy niewstępowania do PKPiR oraz metody wsparcia Komitetu Trzech w tym względzie przez Warszawę trwała od lutego 1947 r. - było to dla całej trójki kolaborującej z reżimem warszawskim niezwykle istotne, gdyż oficerowie PSZ, którzy nie zdecydowali się na wstąpienie do PKPiR lub na powrót do kraju mieli być wg pomysłu brytyjskiego deportowani na teren Niemiec do specjalnego obozu w Osnabrück (ibid., [płk dypl. Józef Kuropieska] Meldunek z dn. 13 II 1947 r., nr 0150/47, b.m., 142). W późniejszym raporcie Chojecki wyjaśniał - na przykładzie Utnika, o którego Komar się dopytywał, gdyż w Warszawie krążyły pogłoski, że został pracownikiem Attachatu Wojskowego w Londynie - że dla zalegalizowania pobytu członków Komitetu na terenie Wlk. Brytanii nie wystarczał sam paszport dyplomatyczny, ale także zgoda Home Office, a tę można było otrzymać, tylko jeśli zgłosiło się ich jako pracowników ambasady; zob. ibid., Pismo płk. Maksymiliana Chojeckiego do gen. Wacława Komara, nr 0500/47, b.m., 12 VII 1947 r., 241.

25 AIPN, Zarząd II Sztabu Generalnego Wojska Polskiego w Warszawie (dalej: Zarząd II SG), 2602/472, Sprawa zespołu Tatar - Nowicki - Utnik i funduszów przez nich administrowanych, b.m., b.d. i nr. kanc., 55. Tadeusz Przybysz (ur. 1921 - zm. 1991) doszedł później do stopnia płk., pracował w Zarządzie II SG - m.in. był attaché wojskowym w Ottawie (1955-1958) i członkiem Polskiej Misji Wojskowej w Wietnamie (1965), zob. AIPN, Kartoteka Zarządu II SG, 003419/1, Kartoteka pracowników Zarządu II SG - Tadeusz Przybysz ur. 1921 r., b.m., b.d., b.p. 
Oddziału II, którą tenże jednak odrzucił; ${ }^{26}$ parę miesięcy później Nowicki nie odmówił Komarowi. Do kontaktów z Tatarem został wyznaczony mąż zaufania Komara w ambasadzie, były „dąbrowszczak”, członek ruchu oporu we Francji i wysoki funkcjonariusz bezpieki (naczelnik Wydziału II Departamentu VII Ministerstwa Bezpieczeństwa Publicznego - MBP), zajmujący przykrywkowo stanowisko radcy handlowego, mjr/ppłk Józef Kutin. ${ }^{27}$ Tenże spotkał się z Tatarem po raz pierwszy 6 października 1947 r. i zwrócił się do niego z prośbą o przekazanie kwoty 200 tys. dolarów (ostatecznie zmniejszonej do 170 tys. dolarów) do 27 października tr. Kutin zauważył, że Tatar

26 AIPN, SWSW, 2386/13890, Protokół przesłuchania Mariana Utnika, Warszawa, 4 XI 1949 r., 14. Nie przeszkadzało mu to ściśle współpracować z Nowickim w jego działalności agenturalnej (a przynajmniej tak wynika z raportów Nowickiego, który praktycznie zawsze pisał: N. i U. zrobili, podjęli decyzję, etc.).

27 Józef Kutin ps. „Antoine”, „Pepe” (ur. 17 X 1911 - zm. 1995) - mjr Brygad Międzynarodowych, ppłk MBP, był pochodzenia żydowskiego, jego rodzice (Adrian i Sara z d. Grinfeld) wyemigrowali do Francji; członek Komunistycznej Partii Francji (1934-1947); funkcjonariusz Komunistycznej Partii Polski (1934-1936), członek Hiszpańskiej Partii Komunistycznej (1936-1939), absolwent Politechniki w Tuluzie (Instytut Elektrotechniczny), inżynier w Zakładach Konstrukcji Linii Elektrycznych „Philipsa” (1932-1936), uczestnik wojny domowej w Hiszpanii w Brygadach Międzynarodowych (szef sztabu brygady, delegat Brygad Międzynarodowych do Komisji Rozbrojeniowej w Genewie), w 1939 r. zmobilizowany do armii francuskiej (odznaczony w 1945 r. Croix de Guerre); uniknął niewoli i działał w komunistycznym ruchu oporu (od 1941 r. w Lyonie, gdzie sformował zalążki batalionów „Carmagnole" i „Liberte”"), w $1943 \mathrm{r}$. aresztowany przez gestapo i w następnym roku osadzony w KL Auschwitz i Mauthausen; w 1945 r. wstąpił do PPR (później do PZPR), lecz wrócił do Francji, gdzie przebywał w latach 1945-1947; odznaczony 16 VII 1946 r. Krzyżem Grunwaldu kl. 3 „w uznaniu bohaterskich zasług ochotników polskich w bojach z niemieckim faszyzmem na polach Hiszpanii w 1936-1939 r. o Polskę Demokratyczną [sic!]”; w styczniu 1947 r. mianowany attaché technicznym w Ambasadzie Polskiej w Paryżu; równocześnie od 20 XI 1945 r. był współpracownikiem MBP jako rezydent wywiadu we Francji; od 1 VII 1947 do 1 III 1949 r., na wniosek Komara, pracownik etatowy (na etacie niejawnym) na stanowisku naczelnika Departamentu VII MBP (AIPN, 01137/168, Akta Personalne Funkcjonariusza / dalej: ap funkc./ MBP Józefa Kutina); w latach 1949-1968 był podsekretarzem stanu w Ministerstwie Handlu Zagranicznego; w marcu 1968 r. wykluczony z PZPR, w 1971 r. wyjechał wraz z rodziną do Francji w celach prywatnych i odmówił powrotu do kraju; we Francji pracował w przemyśle jako inżynier chemik (AIPN, Kartoteka Ogólnoinformacyjna, 419/1, Kartoteka - Józef Kutin ur. 17 X 1911 r.; w punkcie 1 kartoteki wpisano: „zdrada ojczyzny”). Był figurantem (nr rej. 31609) w sprawie nr 46074/II/2 prowadzonej przez Wydział IV Departamentu II MSW: „Pracując w MHZ preferował firmy kapitalistyczne o podejrzanej reputacji, w operacjach z którymi państwo polskie poniosło znaczne straty materialne. Posiadał powiązania $\mathrm{z}$ syjonistami w kraju i za granicą, wrogo działających przeciwko PRL”. Wykluczony z PZPR (AIPN, MSW, 2911/1, Kartoteka - Józef Kutin ur. 17 X 1911 r.). Po 1971 r. także był pod obserwacją wywiadu cywilnego PRL; AIPN, MSW, 01221/40; zob. także https://katalog. bip.ipn.gov.pl/informacje/624745, dostęp styczeń 14, 2020; http://www.combattantvolontairejuif.org/111.html, dostęp styczeń 14, 2020; Jacek Pietrzak, „Polscy uczestnicy hiszpańskiej wojny domowej," Acta Universitatis Lodziensis. Folia Historica 97, (2016): 76, https://doi. org/10.18778/0208-6050.97.04; Monitor Polski 1947, nr 14, poz. 33. 
zażądał kilku dni do „przemyślenia procesu realizacji” oraz dokumentu potwierdzającego realność transakcji. ${ }^{28}$

Najciekawsze jednak jest to, że jak wynika z raportu Kutina dla Komara, 100 tys. dolarów miało trafić do rąk Franciszka Mazura, kierownika Wydziału Organizacyjnego Komitetu Centralnego Polskiej Partii Robotniczej (KC PPR), wówczas przebywającego z wizytą w Szwajcarii. Zapewne Tatar nie zdawał sobie sprawy, że wspiera gotówką partię komunistyczną, a nie, jak sobie szczytnie założył, odbudowę kraju. Kutin sugerował Tatarowi, że dla usprawnienia procesu przekazywania pieniędzy oraz zabezpieczenia funduszu należałoby dokonać „przelania go na moje ręce i ulokowanie pod protekcją dyplomatyczną za moim pokwitowaniem $\mathrm{w}$ formie obustronnie uzgodnionej”. ${ }^{29}$ Tatar miał wyrazić zgodę, ale z góry zasłonił się długim okresem zbierania gotówki z poszczególnych skrytek. Była to z jego strony gra na czas, a do formalnego przekazania całości gotówki na konto ambasady nigdy nie doszło. Kutin ponadto krytycznie oceniał wtajemniczenie przez Tatara w sprawy transferu gotówki ambasadorów: w Wielkiej Brytanii - Jerzego Michałowskiego i we Francji - Jerzego Putramenta, radcy Maksymowicza oraz gen. bryg. Jerzego Kirchmayera, a także Zdzisława Woydata $^{30}$, który reprezentował Komitet Trzech na terenie Francji, obawiając się dekonspiracji całej operacji. ${ }^{31}$ Ostatecznie Tatar przekazał Kutinowi tylko 121 tys. dolarów, z których 67 tys. zostało wydano Mazurowi. ${ }^{32}$

13 grudnia 1947 r. Tatar przekazał ze swojej „meliny” na terenie Luksemburga, w formie depozytu, 860 dolarów w złocie (17 szt. dużych i 52 szt. małych monet), 65 tys. dolarów w gotówce oraz 170 tys. franków belgijskich

28 AIPN, SWSW, 2306/13909/1, [Józef Kutin] Raport nt. spotkań ze Stanisławem Tatarem w październiku 1947 r., b.m., 19 X 1947 r., 278.

29 Ibid., 279.

30 Zdzisław Woydat (ur. 22 X 1899 - zm. 16 IX 1973) - przed 1939 r. działacz młodzieży prawicowo-radykalnej, sekretarz generalny Państwowego Banku Rolnego i jeden z dyrektorów w polskiej filii Young Men's Christian Association (YMCA); w czasie II wojny światowej znajdował się we Francji, gdzie od początków kierował polską filią YMCA na emigracji, należał do grona bliskich współpracowników Stanisława Zabiełły (którego znał ze studiów) - został przez niego mianowany w czerwcu 1940 r. delegatem Polskiego Czerwonego Krzyża na okręg Tuluza; Zabiełło oceniał go następująco: „Wykazał duże zdolności organizacyjne i sprężystość w działaniu, ale był raczej nie lubiany przez współpracowników z powodu twardej ręki, stawiania dużych wymagań i skłonności do zapisywania wszystkich osiągnięć w pracy na swoje konto". Zob. Stanisław Zabiełło, Na posterunku we Francji (Warszawa: Wyd. Pax, 1967), 113. Prywatnie Woydat był szwagrem Tatara - bratem jego żony Marii z d. Woydat.

31 AIPN, SWSW, 2306/13909/1, [Józef Kutin] Raport nt. spotkań z Stanisławem Tatarem w październiku 1947 r., b.m., 19 X 1947 r., 280, 281.

32 AIPN, Zarząd II SG, 2602/472, Sprawa zespołu Tatar - Nowicki - Utnik i funduszów przez nich administrowanych, b.m., b.d. i nr. kanc., 56. 
konsulowi w Luksemburgu ${ }^{33}$ (i zarazem zaufanemu, jak się wydawało, komuniście) Zygmuntowi Sobolewskiemu ${ }^{34}$. Dziewięć dni później - 22 grudnia - zobowiązał Kutina do likwidacji depozytu, ${ }^{35} \mathrm{o}$ czym zresztą poinformował też konsula. ${ }^{36}$ Według powojennych wyjaśnień Tatara konsula Sobolewskiego polecił mu Putrament jako człowieka godnego zaufania i mogącego podjąć luksemburski fragment „Drawy” z zadaniem dostarczenia go do Paryża. Istnieją przekazy, wg których Sobolewski miał w drodze do Paryża, gdzie jechał z Luksemburga w celu zwrotu depozytu, wypadek samochodowy i znalazł się w szpitalu. Tam skonstatował zaginięcie pasa ze złotymi monetami, co miało stanowić ostateczny powód do ucieczki na Zachód. Mówiło się także, że impulsem do ucieczki była kradzież depozytu Tatara (tak też twierdził po wojnie sam Tatar). Żona Sobolewskiego, poetka i pisarka Ewa Szemplińska-Sobolewska, twierdziła później, że depozyt Tatara został zwrócony w Ambasadzie w Paryżu ${ }^{37}$ - wydaje się, że jej wersja

33 AIPN, SWSW, 2306/13909/1, Oświadczenie konsula Zygmunta Sobolewskiego o przejęciu depozytu gen. Stanisława Tatara, b.m., 13 XII 1947 r., 297, 298.

34 Zygmunt Sobolewski (ur. 1910 - zm. 1951?) - por. lWP, przedwojenny działacz komunistyczny, dziennikarz, literat, w 1939 r. przedostał się wraz z żoną, młodą pisarką o komunistycznych poglądach Ewą Szemplińską-Sobolewską, do sowieckiej strefy okupacyjnej; w latach 1939-1941 mieszkał z żoną (która osiągnęła status „polskiej pisarki radzieckiej”) we Lwowie; był członkiem Związku Patriotów Polskich, w 1943 r. wstąpił do organizowanej przez ppłk. dypl. Zygmunta Berlinga 1 Dywizji Piechoty im. Tadeusza Kościuszki i został w lipcu tr. dowódcą 1 Samodzielnego Batalionu Kobiecego im. Emilii Plater; odwołany ze stanowiska już w sierpniu 1943 r., zadenuncjowany za jakoby prowadzenie agitacji antysowieckiej i wysłany karnie do Riazania; od 1944 r. ponownie w I Korpusie Polskim w ZSRS; w 1945 r. został dyrektorem administracyjnym w Wydawnictwie „Nowa Epoka”, a w 1946 r. został konsulem RP w Luksemburgu; od zakończenia wojny zarówno on, jak i jego żona stopniowo odrzucali ideologię komunistyczną, w związku ze swoimi doświadczeniami z pobytu w ZSRS w latach 1939-1944 oraz w Polsce Ludowej w latach 1944-1946; w 1948 r. małżeństwo zaplanowało ucieczkę na zachód, którą zrealizowano, wyjeżdżając prywatnym samochodem do Paryża, potem do Marsylii i wreszcie do Rzymu, gdzie przy pomocy ambasadora Rządu na Uchodźstwie przy Watykanie Kazimierza Papée uzyskali nowe paszporty na fałszywe nazwisko: Piotr i Jolanta Korwin-Milewski; z Rzymu wyjechali do Maroka; 31 I 1951 r. Sobolewski wsiadł na statek Novo Francisco płynący z Casablanki do Rzymu i słuch o nim zaginął; statek najprawdopodobniej zatonął, a zwłoki Sobolewskiego wyłowiono blisko pięć lat później u wybrzeży Andaluzji, gdzie 25 XI 1955 r. doszło do ekshumacji jego szczątków i rozpoznania ich przez żonę, zob. Olga Soporowska-Wojtczak, „Twórczość Elżbiety Szemplińskiej-Sobolewskiej," dysertacja doktorska, Uniwersytet Adama Mickiewicza, Poznań, 2013, passim.

35 AIPN, SWSW, 2306/13909/1, List Stanisława Tatara do Józefa Kutina, b.m., 22 XII 1947 r., 294, 295.

36 Ibid., List Stanisława Tatara do Zygmunta Sobolewskiego, b.m., 22 XII 1947 r., 299.

37 Co by potwierdzało trop zasugerowany przez Zbigniewa Siemaszkę, że dolary i złoto z Luksemburga ostatecznie trafily do kieszeni funkcjonariuszy wywiadu komunistycznego; Zbigniew Sebastian Siemaszko, Działalność generała Tatara 1943-1949 (Lublin: Norbertinum, 2004), 148. 
była najbliższa prawdy, gdyż w depeszy Komara do Chojeckiego z 31 stycznia 1948 r. o ucieczce Sobolewskich znajduje się informacja tylko o tym, że mają oni jakieś dokumenty Tatara, a o pieniądzach i złocie nie ma ani słowa. ${ }^{38}$ Zresztą Komar sugerował, żeby Tatar użył swoich kontaktów dla ustalenia miejsca pobytu Sobolewskich. ${ }^{39}$

Wraz początkiem $1948 \mathrm{r}$. operacja transferu gotówki z funduszu „Drawa" powoli nabierała dynamiki. 19 stycznia wyruszył do kraju, via Paryż, Nowicki ${ }^{40} \mathrm{z}$ kwotą 160 tys. dolarów (do Warszawy przyjechał 1 lutego). ${ }^{41}$ W Polsce przebywał przez trzy tygodnie, do 21 lutego. Przydzielono mu jako adiutanta - a faktycznie anioła stróża - oficera kontrwywiadu z Departamentu I MBP por. Fryderyka Zbiniewicza ${ }^{42}$ (nota bene później pułkownika i pracownika naukowego Wojskowego Instytutu Historycznego im. Wandy Wasilewskiej - WIH). ${ }^{43}$ Jednak po jego powrocie sprawy zaczęły się komplikować, a w łonie Komitetu Trzech pojawiły się coraz większe tarcia i konflikty, wynikające $\mathrm{z}$ faktu apodyktycznego charakteru Tatara oraz $\mathrm{z}$ tego, że płk dypl. Nowicki został tajnym współpracownikiem wywiadu wojskowego Polski Ludowej. ${ }^{44}$ Komar przeszedł w ten sposób do ofensywy

W raporcie dla Mariana Spychalskiego z 12 VII 1948 r. Komar odnotowywał depozyt luksemburski jako skradziony przez Sobolewskiego; zob. Witold Bagieński, Wywiad cywilny Polski Ludowej w latach 1945-1961, t. 2 (Warszawa: Wyd. Instytutu Pamięci Narodowej, 2017), 20.

38 Sprawa z Sobolewskim miała się odbyć bez zgody centrali wywiadu w Warszawie - w résumé sprawy TUN, jaki przygotowano w Oddziale II SG, oskarżono Sobolewskich o ucieczkę z depozytem Tatara, niedwuznacznie sugerując, że bez dolarów ich plan by się nie powiódł. AIPN, Zarząd II SG, 2602/472, Sprawa zespołu Tatar - Nowicki - Utnik i funduszów przez nich administrowanych, b.m., b.d. i nr. kanc., 56.

39 AIPN, SWSW, 2306/13909/1, Szyfrogram Wacława Komara do Maksymiliana Chojeckiego, nr 162, b.m., 31 I 1948 r., 303.

40 Ibid., Szyfrogram Wacława Komara do Maksymiliana Chojeckiego, nr 74, b.m., 19 I 1948 r., 301.

41 AIPN, Zarząd II SG, 2602/472, Sprawa zespołu Tatar - Nowicki - Utnik i funduszów przez nich administrowanych, b.m., b.d. i nr. kanc., 56.

42 Ibid.

43 Fryderyk Zbiniewicz (ur. 7 VII 1922 - zm. 6 XI 1996) - zanim został pracownikiem WIH i autorem takich „dzieł”, jak: Armia Polska w ZSRR: studia nad problematyka pracy politycznej (Warszawa: Wyd. Ministerstwa Obrony Narodowej, 1963) czy też Zarys historii międzynarodowego ruchu robotniczego i dziejów myśli socjalistycznej: strategia i taktyka międzynarodowego ruchu robotniczego w latach II wojny światowej (Warszawa: Wyższa Szkoła Nauk Społecznych przy KC PZPR, 1973), był funkcjonariuszem MBP i SB; zob. AIPN, 0193/6480, ap funkc. SB Fryderyka Zbiniewicza.

44 Nigdzie nie udało mi się znaleźć oficjalnego dokumentu poświadczającego współpracę agenturalną Nowickiego (także nie udało się ustalić pseudonimu, jakim się posługiwał w korespondencji z centralą - na raportach takowego nie używał). Natomiast już po wyjściu z więzienia Wydział Kadr Zarządu II SG wystawił mu, na podstawie potwierdzenia pisemnego gen. Komara z 5 II 1959 r., że od 1 VII 1947 r. do 4 XI 1949 r. służył w wywiadzie PRL na placówce 
(już wcześniej próbował zwerbować Utnika), nie tylko zyskując wpływ na decyzje członków Komitetu, ale przede wszystkim obracając ich przeciwko sobie; posunięcie godne prawdziwego spymastera. ${ }^{45} \mathrm{O}$ swojej współpracy agenturalnej z Oddziałem II raczej na pewno Nowicki poinformował Utnika - można tak sądzić po lekturze raportów, jakie wysyłał do Warszawy, a które często pisał w ich wspólnym imieniu.

Rozłam w Komitecie pogłębiał się, a Nowicki zaczął przesyłać do Warszawy regularnie raporty na temat Tatara oraz różnych przez niego podejmowanych działań. Zwrotnie otrzymywał od szefa Oddziału II dyspozycje oraz zadania do realizacji, co jednoznacznie nadawało jego działaniom cech współpracy agenturalnej. 1 marca $1948 \mathrm{r}$. informował m.in. o wiernym Tatarowi personelowi na terenie Francji, w skład którego wchodzili: Woydat (brat żony Tatara, prezes YMCA w Paryżu) oraz jego żona; Janina Michalska-Pronaszko „Tita”, łączniczka Armii Krajowej (AK), szefowa sekretariatu i łączności ostatniego dowódcy AK gen. bryg. Leopolda Okulickiego, „prawa ręka Tatara z okresu konspiracji w kraju, dawny flirt Tatara”; ${ }^{46}$ Anna Romanowska, córka gen. Władysława Andersa, „ma prowadzić pensjonat na farmie Tatara pod Paryżem”, ${ }^{47}$ ppłk Władysław Garlicki, dawny podkomendny Tatara z 3 Pułku Artylerii Lekkiej (pal) oraz z Wydziału Artylerii KG AK ps. „Bogumił”, „przewidywany na kierownika domu-klubu w Paryżu”, ${ }^{48}$ kpt. Eugeniusz Konopacki ps. „Trzaska”, dowódca batalionu AK Szarych Szeregów „Wigry” w powstaniu warszawskim, brat żony Woydata „prawdopodobnie wkrótce dojedzie”. ${ }^{49} \mathrm{Na}$ terenie Wlk. Brytanii Utnik i Nowicki wśród wiernego Tatarowi personelu wymienili: kpt.

przy Ambasadzie w Londynie; CAW-WBH, Kolekcja Teczek Akt Personalnych (dalej: TAP), 742/61/1284, TAP Stanisława Nowickiego, Szef Wydziału Kadr Zarządu II SG [mjr Majewski] do szefa Oddziału VI Departamentu Kadr MON, nr 532/0131/59, b.m., 19 II 1959 r., b.p. Jeśli zaś chodzi o początek jego działalności agenturalnej, to Chojecki zdaje się nie do końca ufał Nowickiemu, gdyż napisał do Komara: „Melduję, że po powrocie z Kraju płk Nowicki poinformował mnie o poleceniu przekazywania Wam przez niego specjalnych materiałów. W związku z powyższym przedstawiam, bez kontroli, załączoną kopertę przekazaną mi przez płk. Nowickiego. Proszę o potwierdzenie zarządzenia”, zob. AIPN, WSW, 2306/13910, Pismo płk. Maksymiliana Chojeckiego do gen. Wacława Komara, nr 098/48, b.m., 4 III 1948 r., 47.

45 A przy okazji obnażające zupełny brak spójności wewnątrz Komitetu, która jako jedyna mogła stanowić jakiś argument $\mathrm{w}$ niebezpiecznej grze $\mathrm{z}$ wywiadem komunistycznym. Rozgrywanie jednych przeciwko drugim dzięki rozpoznaniu konfliktów rozsadzających grupę od środka, wejście w posiadanie wiedzy nt. kompromitujących spraw prywatnych - oto efekt zwerbowania Nowickiego przez Komara. Jest to także dowód naiwności całej grupy, która nie zdawała sobie sprawy, z jak niebezpiecznym i perfidnym partnerem mają do czynienia.

46 AIPN, SWSW, 2306/13909/2, [Raport poufny Stanisława Nowickiego dla Wacława Komara], b.m., 1 III 1948 r., 311.

47 Ibid.

48 Ibid.

49 Ibid. 
Mieczysława Dziekońskiego, „dawny adiutant Tatara, obecnie kierownik farmy Tatara pod Londynem” ${ }^{50}$ oraz jego żona, „przypuszczalnie dawny flirt T.”51; bliżej nieznanego „płk Rogozińskiego" ${ }^{52}$, który miał być dawnym oficerem Tatara z Polski, „obecnie strażnik mieszkania i osoby Tatara” "53; Irenę Nowak - „córka górnika, emigranta polskiego we Francji, obecnie dama serca Tatara, wiek 19-20 lat" ${ }^{34}$. Zwraca uwagę obyczajowa strona tych opinii - większość kobiet wymienionych przez Nowickiego miała być dawnym lub obecnym "flirtem” Tatara. ${ }^{55}$

W tymże raporcie Nowicki zarzucał Tatarowi m.in., że unieważnił im dostęp do depozytów funduszu „Drawa” na terenie Francji; że prowadzi podwójną grę i rzeczywiście stara się o dokumenty na stały pobyt w Wlk. Brytanii. Nowicki donosił, że po swoim powrocie z kraju Tatar zażądał od niego spotkania w cztery oczy, podczas którego odnosił się z lekceważeniem do kierownictwa reżimu komunistycznego. Twierdził, że Tatar posądzał Utnika o nielojalność. Dla oficerów komunistycznego wywiadu szczególnie cenna była informacja, że Tatar planował ponownie pojechać do kraju, ażeby spotkać się z Marianem Spychalskim dla omówienia utworzenia „fundacji AK". Ponadto sugerował, że Tatar planuje wyjazd do Belgii dla przejęcia zdeponowanej tam części „Drawy”, sugerując przeszkodzenie mu w wyjeździe. W innym miejscu oskarżał Tatara o dążenie do wybielenia własnego aktu niesubordynacji - czy też bez eufemizmu: zdrady - poprzez kontakty z gen. Stanisławem Kopańskim i politykiem Polskiej Partii Socjalistycznej (PPS) Janem Kwapińskim oraz rozpowszechnianie o sobie plotek jako niezależnym patriocie, niechodzącym na pasku Warszawy. ${ }^{56}$

50 Ibid. Dziekoński nie był adiutantem Tatara, lecz adiutantem 3 pal, którym tenże dowodził do 1939 r.

51 Ibid.

52 Być może nazwisko zostało przekręcone lub posługiwał się pseudonimem, gdyż oficera o takim nazwisku i takim stopniu w WP (przed 1939 r.) i w PSZ nie było.

53 AIPN, SWSW, 2306/13909/2, [Raport poufny Stanisława Nowickiego dla Wacława Komara], b.m., 1 III 1948 r., 311.

54 Ibid.

55 Zwracał na to uwagę także pierwszy biograf Tatara - najbardziej znanym romansem londyńskim tego oficera była Stefania Liberman z domu Sigalin, żona posła i działacza PPS Hermana Libermana, po jego śmierci sekretarka i zauszniczka (oraz najprawdopodobniej kochanka) Stanisława Mikołajczyka. Według Siemaszki Libermanowa szczególnie blisko związała się z Tatarem po wyjeździe Mikołajczyka do Polski; robiła mu nawet sceny zazdrości o młodszą rywalkę, czyli wspomnianą Irenę Nowak, a po jej śmierci likwidujący jej sprawy działacz PSL Franciszek Wilk odnalazł na strychu jej londyńskiego domu szkicownik z rysunkami nagiego Tatara; zob. Siemaszko, Działalność, 249-251.

56 AIPN, SWSW, 2306/13909/2, [Raport poufny Stanisława Nowickiego dla Wacława Komara], b.m., 1 III 1948 r., 310-313. 
W tym samym raporcie Nowicki ujawnił zlecone mu przez wywiad komunistyczny zadanie zorganizowania sieci agencyjnej o kryptonimie „Sen”. Uznał to zadanie w ich sytuacji za niezwykle trudne, ze względu na jawne opowiedzenie się po stronie rządu warszawskiego. Pomimo tego podjęli działania - Utnik zobowiązał się odnowić stare znajomości w celu znalezienia stałego informatora $\mathrm{w}$ „centralnych wojskowych kołach emigracyjnych" ${ }^{57}$ którego należało związać wynagrodzeniem pieniężnym, co miało umożliwić w przyszłości „przykręcenie śruby nacisku” ${ }^{5}$. Sieć „Sen” miała także działać na terenie Francji - 22 lutego 1948 r. Nowicki wydelegował do Paryża byłego oficera Oddziału VI kpt. Jana Majeranowskiego ps. „Mar”, który miał być szefem tamtejszej placów „Snu” i „wtyczką” Nowickiego w strukturach wiernych Tatarowi. Legendując się w Paryżu, Majeranowski miał atakować Nowickiego i Utnika oraz wszelkimi sposobami uzyskać akceptację ze strony ekipy wiernej Tatarowi oraz miał zdobyć zaufanie ludzi związanych z rządem na uchodźstwie - zakres jego działania obejmował więc inwigilację Tatara i jego francuskiego personelu oraz działalność agenturalną wobec wszelkich środowisk wrogich rządowi w Warszawie. Regularną pracę wywiadowczą Majeranowski miał rozpocząć z dn. 1 kwietnia 1948 r. ${ }^{59}$ Do raportu został dołączony list, w którym Nowicki wprost alarmuje Komara o możliwości wycofania się Tatara $\mathrm{z}$ umowy z Warszawą i ucieczki z pieniędzmi ${ }^{60}$ - zapewne chodziło o możliwość głębokiego zakonspirowania się na terenie Francji, wzorem Jana Kamieńskiego (z ramienia Sztabu Głównego PSZ i za akceptacją rządu emigracyjnego sprawował pieczę nad częścią funduszu „Drawa” przejętego od Tatara na terenie Niemiec w $1946 \mathrm{r}^{61}$ ).

Zwrotną pocztą gen. Komar potwierdził zgodę na zarysowany przez Nowickiego plan działania sieci "Sen”, ${ }^{62}$ ponadto zadaniował bezpośrednio obu oficerów, zlecając im przeprowadzenie operacji o kryptonimie „Sowa” ${ }^{63}$ - pod którym kryło się zadanie rozpracowywania ruchu lewicowego (PPS) i ludowego (Stronnictwo Ludowe) na emigracji. Ustalono metody łączności, którą oparto na oficjalnych kanałach via attaché wojskowy w Londynie, z tym, że ppłk Chojecki nie miał prawa otwierać korespondencji pomiędzy Komarem

$57 \quad$ Ibid., 313.

58 Ibid.

59 Ibid., 314. Do raportu dołączone były także fotokopie, odpisy i oryginalne dokumenty PSZ i AK jako dodatkowe „wiano” agenturalnej pracy.

60 Ibid., List Stanisława Nowickiego do Wacława Komara, b.m., 3 III 1948 r., 398.

61 Koreś, „Zanim,” 418 i n.

62 AIPN, Zarząd II SG, 2602/474, [gen. Wacław Komar] Notatka w sprawie akcji „Sen”, b.m., [26 III 1948 r.], 70.

63 Ibid., [gen. Wacław Komar] Notatka w sprawie zadania „Sowa”, b.m., [26 III 1948 r.], 69. 
a Nowickim (i w drugą stronę). 4 marca 1948 r. Chojecki prosił Komara o potwierdzenie tego faktu, co zostało uczynione w poczcie zwrotnej. ${ }^{64}$

W połowie marca $1948 \mathrm{r}$. do rąk Tatara trafiła dość obcesowa depesza od Komara ${ }^{65}$ w której wprost żąda od Komitetu Trzech przekazania radcy Kutinowi w Paryżu 1,5 mln dolarów, ponoć w celu zakupów sprzętu ${ }^{66}-$ prawdziwego przeznaczenia tych pieniędzy nie znamy, ale na pewno całość nie miała pójść na zakupy. Komar z pełną świadomością zagrał z Tatarem va banque, gdyż dzięki posiadaniu agentury wewnątrz Komitetu mógł poznać jego reakcję na tę propozycję. $Z$ punktu widzenia Komara i reprezentowanych przez niego władz państwowych i kierownictwa partyjnego takie rozwiązanie uprościłoby procedurę zakupów - zniknęłaby konieczność każdorazowego zwracania się do Tatara o wyłożenie potrzebnych sum, jak choćby 7 lutego 1948 r., gdy szef komunistycznego wywiadu przysłał polecenie wydatkowania 12 tys. funtów szterlingów na hamownie dla przemysłu motoryzacyjnego wg zaleceń inż. Otowskiego ${ }^{67}$ Każdorazowo w takiej sytuacji, bez względu na kategoryczny i ultymatywny charakter korespondencji przychodzącej z Warszawy, to właśnie Tatara trzeba było prosić o wyłożenie potrzebnej sumy. Zaczynało to być dla Komara - i zapewne dla jego mocodawców - coraz bardziej irytujące.

A Tatar wcale nie zamierzał zbyt szybko pozbyć się argumentu, który stanowił fundament jego pozycji wobec Warszawy. Nowicki meldował w raporcie z 18 marca 1948 r., że dzień wcześniej odbyła się dyskusja w czasie posiedzenia Komitetu, w trakcie której Tatar sprzeciwiał się oddaniu całej sumy na raz Kutinowi. W zamian proponował przekazywanie „Drawy” partiami, w zalakowanych paczkach, na ręce attaché wojskowych w Londynie, Paryżu i Brukseli. ${ }^{68}$ Zdając sobie sprawę z niezadowolenia, jakie jego pomysł mógł wywołać u Komara, zdecydował się uzyskać zgodę na realizację na wyższym szczeblu. W tym celu napisał list do wiceministra obrony narodowej, zastępcy przewodniczącego Państwowej Komisji Bezpieczeństwa

64 AIPN, SWSW, 2306/13910, Pismo płk. Maksymiliana Chojeckiego do gen. Wacława Komara, nr 098/48, b.m., 4 III 1948 r., 47.

65 Już od września 1947 r. domagał się coraz usilniej „stałych informacyj o pracy, nastawieniu i ustosunkowaniu się Tatara i jego otoczenia do realizacji znanego Wam planu, dotyczących zarządzanych przez niego funduszy”; zob. ibid., Szef Oddziału II SG [Wacław Komar] do Attaché Wojskowego w Londynie [Maksymilian Chojecki], nr 0029/22/47, b.m., 12 IX 1947 r., 106, mps.

66 AIPN, SWSW, 2306/13909/2, [gen. Wacław Komar] Depesza szyfrowa do Stanisława Tatara, Stanisława Nowickiego i Mariana Utnika, b. nr. kanc., b.m., [9 III 1948 r.], 330.

67 AIPN, Zarząd II SG, 2602/472, Sprawa zespołu Tatar - Nowicki - Utnik i funduszów przez nich administrowanych, b.m., b.d. i nr. kanc., 57.

68 AIPN, SWSW, 2306/13909/2, [Raport poufny Stanisława Nowickiego dla Wacława Komara], b.m., 18 III 1948 r., 332. 
oraz członka Biura Politycznego PPR (następnie PZPR) gen. dyw. Spychalskiego, w którym także proponował utworzenie w kraju ekspozytury Komitetu Trzech, mającej reprezentować interesy tzw. „fundacji”. Plan był sprytny - gdyż gra z komunistami przenosiła się do najwyższych kręgów władz państwowych i partyjnych - choć już niebawem protekcja towarzysza „Marka” miała stać się pocałunkiem śmierci. Tego jednak wiedzieć wówczas nie mógł. W kontrze do pomysłów Tatara Nowicki zapewniał Komara, że podejmą z Utnikiem działania zmierzające w kierunku rozbicia Komitetu oraz podziału środków na trzy części - swoje obiecywali niezwłocznie oddać Warszawie, a Tatara chcieli uwikłać w likwidację spraw inwestycji w Wlk. Brytanii, Francji i Belgii. ${ }^{69}$

Być może Tatar domyślał się dwulicowej gry swoich kolegów z Komitetu, gdyż 22 marca 1948 r. koncyliacyjnie zaproponował wspólne zredagowanie listu do Spychalskiego. Nowicki donosił Komarowi, że to gra, która ma za zadanie odwlec przekazanie pieniędzy oraz sugerował, że Tatar dąży do przejęcia kontroli nad całą „Drawą” oraz do wyeliminowania ich jako czynników decyzyjnych z całej rozgrywki. Sugerował ponadto, że krajowa ekspozytura Komitetu ma być obsadzona przez wierny Tatarowi personel i stanowić będzie jego asekurację na wypadek, gdyby musiał opuścić Wlk. Brytanię - meldował przy tym, że zaczną wprowadzać w życie swój plan (podziału „Drawy” na trzy części), gdy Warszawa odpowie na propozycję Tatara. ${ }^{70}$ List do Spychalskiego wyszedł z Londynu tegoż dnia, równolegle $\mathrm{z}$ donosem Nowickiego, via attaché wojskowy płk Chojecki ${ }^{71}-\mathrm{w}$ liście Tatar pisał o 2247362 dolarach, które chce przekazać w gotówce do kraju, w serii przesyłek przekazywanych attaché wojskowym oraz około 100 tys. dolarów (choć były to funty szterlingi) na koncie „fundacji” (czyli Polish Self-Help Association); sprawę przekazania tej ostatniej sumy chciał omówić osobiście ze Spychalskim. ${ }^{72}$ Tatar wyraźnie chciał sam rozstrzygać sprawy „Drawy”. Zaskakująco dla Nowickiego (i zapewne Komara) - Spychalski zgodził się na propozycję Tatara, być może, żeby nie przeciągać sprawy sporami o sprawy techniczne. ${ }^{73}$ Przekazał swoje pełnomocnictwa, do załatwienia kwestii poruszonych w liście, na ręce attaché w Londynie Chojeckiego i w ten sposób zdegradował pozycję zaufanego Komara, radcy Kutina, w grze o dolary;

\footnotetext{
69 Ibid.

70 Ibid., [Raport poufny płk. dypl. Stanisława Nowickiego dla Wacława Komara], b.m., 22 III 1948 r., 334.

71 Ibid., Pismo płk. Maksymiliana Chojeckiego do gen. Wacława Komara, nr 0136/48, b.m., 22 III 1948 r., 336.

72 Ibid., List gen. Stanisława Tatara do gen. Mariana Spychalskiego, b.m., 22 III 1948 r., 337.

73 Ibid., List gen. Mariana Spychalskiego do Stanisława Tatara, Stanisława Nowickiego i Mariana Utnika, b.m., b.d. i nr. kanc., 341.
} 
niemniej realizacja przekazywania dolarów dalej pozostawała w gestii aparatu podległego szefowi Oddziału II. ${ }^{74}$ Sęk tkwił w tym, że pojawienie się Spychalskiego, jako gwaranta porozumienia z Tatarem, ${ }^{75}$ mieszało mu szyki, wzmacniając pozycję przewodniczącego Komitetu Trzech, oraz utrudniało mu prowadzenie działań przeciwko niemu kierowanych.

7 kwietnia 1948 r. Nowicki w kolejnym raporcie do Komara ujawnił, że poprzez placówkę „Sen” w Paryżu (kpt. Majeranowski „Mar”) stara się odnaleźć miejsce przechowywania dolarów. „Mar” stwierdził, że na pewno dolarów nie ma w Paryżu, a podejrzenia skierował na firmę "Sada” na płd. Francji, gdzie jeździł zaufany Tatara - Woydat. Donosił też, że Woydat utracił stanowisko prezesa YMCA, które pozwalało mu bezpiecznie działać na terenie Francji - widzieli w tym zagrożenie dla „Drawy”, której, jak twierdzili, szukali także ludzie związani z rządem emigracyjnym; wg tego raportu Tatar prowadził na terenie Londynu cichą akcję oczerniania Utnika, którego określał jako najbardziej uwikłanego we współpracę z Warszawą ${ }^{76}$ Powstaje pytanie, czy akcja szukania dolarów z „Drawy” ukrytych przez Tatara i Woydata we Francji została zlecona $\mathrm{z}$ Warszawy, czy też była to „oddolna" inicjatywa buntujących się wspólników?

Przekazywanie „Drawy” rozpoczęło się, choć z oporami - głównie ze strony Tatara, który chciał cały czas grać na zwłokę - w trzeciej dekadzie kwietnia 1948 r. od depozytu belgijskiego. Chojecki raportował Komarowi 22 kwietnia 1948 r., że rozpoczęto likwidację „Drawy” od Brukseli, gdyż wpadł na jej belgijski trop wywiad rządu emigracyjnego. ${ }^{77}$ Być może trop podrzuciło Biuro Planowania płk. dypl. Franciszka Demela, które posiadało swoją centralę właśnie w Brukseli - jest to hipoteza, której potwierdzenia trzeba ciągle szukać. Chojecki meldował, że Tatar gra na zwłokę z przyczyn politycznych i osobistych - oraz kreuje się na jedynego, który

\footnotetext{
74 Ibid., List gen. Mariana Spychalskiego do Stanisława Tatara, b.m., b.d. i nr. kanc., 343.

75 Przejęcie kontroli nad sprawą Komitetu Trzech okazało się dla Spychalskiego, w niedalekiej przyszłości, sprawą obciążającą. To zeznania m.in. Tatara stały się podstawą do jego aresztowania; Robert Spałek, Komuniści przeciwko komunistom. Poszukiwania wroga wewnętrznego w kierownictwie partii komunistycznej w Polsce w latach 1948-1956 (Warszawa: Instytut Pamięci Narodowej i Wyd. Zysk i S-ka, 2014), 450 i n. Także dla Komara i innych „Hiszpanów” w nią zaangażowanych (Stanisław Flato, Witold Leder) sprawa TUN miała się zakończyć kłopotami - Sławomir Cenckiewicz ujął to niezwykle trafnie: „W ten sposób bodaj największy sukces wywiadu Komara stał się zapowiedzią jego największej osobistej klęski", zob. Sławomir Cenckiewicz, Długie ramię Moskwy. Wywiad wojskowy Polski Ludowej 1943-1991 (Poznań: Wyd. Zysk i S-ka, 2011), 75, 76.

76 AIPN, SWSW, 2306/13909/2, [Raport poufny Stanisława Nowickiego dla Wacława Komara], b.m., 7 IV 1948 r., 345, 346.

77 Ibid., Pismo płk. Maksymiliana Chojeckiego do gen. Wacława Komara, nr 00173/48, b.m., 22 IV 1948 r., 357.
} 
jest $\mathrm{w}$ stanie pokonać wszelkie trudności z wydaniem pieniędzy. ${ }^{78} \mathrm{~W}$ końcu miesiąca wyjechał do Brukseli Utnik, który miał przekazać 380 tys. dolarów ${ }^{79}$ kurierowi Oddziału II, kpt. Tadeuszowi Lityńskiemu. ${ }^{80}$ Kurier przejął dwie paczki („pakiety nr 11 i 12”) po 195 tys. dolarów 27 kwietnia 1948 r., ${ }^{81}$ przy czym attaché dodał: „Uprzedziliśmy bezspornie zamiary londyńskiej dwójki, których straż przednia już udała się na tamtejszy teren [zapis jak w oryginale - D. K.]”; 82 dwa dni później Chojecki meldował: „Belgia czysta, za wyjątkiem nieruchomości, której sprawa jest w toku, lecz wymaga czasu" ${ }^{83} 31$ kwietnia wyjechał do Paryża Nowicki w celu rozpoczęcia przekazywania depozytów francuskich, ${ }^{84}$ które miał przejąć ppłk Leon Krajewski - p.o. attaché wojskowego w Paryżu; ${ }^{85}$ powierzenie zadań kurierskich atta-

78 Ibid., 355-357.

79 Ibid., Depesza szyfrowa Maksymiliana Chojeckiego do Wacława Komara, b.m., 22 IV 1948 r., b. nr. kanc., 353.

80 Tadeusz Lityński (ur. 12 I 1910 - zm. ?) - mjr lWP, pracownik Zarządu II SG; zob. AIPN, Ministerstwo Obrony Narodowej (dalej: MON), 2174/8320, TAP T.[adeusza] Lityńskiego; zob. także ibid., Zarząd II SG, 2602/9465, TAP Tadeusza Lityńskiego. Za wskazanie oficera serdecznie dziękuję Bartoszowi Kapuściakowi.

81 AIPN, SWSW, 2306/13909/2, Depesza szyfrowa Maksymiliana Chojeckiego do Wacława Komara, b.m., 27 IV 1948 r., b. nr. kanc., 364. Ponadto wyszedł z Londynu skromny „pakiet” nr 14 (4 tys. dolarów) oraz „pakiet” nr 13, który miał zawierać zestawienia rachunkowe (ale nie wiadomo, czy jakąś gotówkę); zob. ibid., Depesza szyfrowa Maksymiliana Chojeckiego do Wacława Komara, b.m., 19 V 1948 r., b. nr. kanc., 378.

82 Ibid. Chojecki zapewne się nie orientował, że stałym rezydentem wywiadu emigracyjnego w Belgii był płk dypl. Michał Rybikowski - zachowała się fragmentaryczna korespondencja pomiędzy nim a płk. dypl. Demelem z 1950 i 1951 r. (Instytut Polski i Muzeum im. gen. Sikorskiego, Kol. Franciszka Demela, 195/6), który wcześniej także urzędował w Brukseli. W końcu lat czterdziestych organizacja wywiadowcza 2 Korpusu (tzw. Biuro Planowania kierowane przez Demela) oraz pozostałości po „dwójce” (działające w ramach brytyjskich Secret Inteligence Service i kierowane przez płk. dypl. Stanisława Gano) prowadziły działania wywiadowcze i kontrwywiadowcze na kontynencie o charakterze antysowieckim, w czym oczywiście mieściły się działania przeciwko wywiadowi Polski Ludowej.

83 AIPN, SWSW, 2306/13909/2, Depesza szyfrowa Maksymiliana Chojeckiego do Wacława Komara, b.m., 29 IV 1948 r., b. nr. kanc., 368.

84 Ibid., Depesza szyfrowa Maksymiliana Chojeckiego do Wacława Komara, b.m., 30 IV 1948 r., 370.

85 Leon Krajewski (ur. 13 III 1910 - zm. ?) - ppłk lWP (12 X 1946 r.), w WP dowódca kompanii w 80 pp, w niewoli niemieckiej 1939-1945, w lWP od 13 VII 1945 r. - absolwent Wyższej Szkoły Oficerskiej w Rembertowie (listopad 1945 r.), następnie referent w Gabinecie MON (do września 1946 r.), zastępca attaché w Paryżu (do lutego 1947 r.) i p.o. attaché wojskowego w Paryżu (do listopada 1948 r.); po powrocie z placówki kierownik Sekcji w Wydziale IV Oddziału II SG, do 10 I 1950 r., gdy został zwolniony ze służby wojskowej „ze względu na braki wyrobienia politycznego i zrozumienia obecnej rzeczywistości”; zob. AIPN, Zarząd II SG, 2602/9495, TAP Leona Krajewskiego, Karta ewidencji personalnej oficera WP - Krajewski Leon, s. Józefa, nr 24172, 13, 14; za udostępnianie akt serdecznie dziękuję Bartoszowi Kapuściakowi. 
ché jest dowodem wagi, jaką przyznawano w centrali wywiadu tej sprawie. W pierwszych dniach maja kurier otrzymał od Nowickiego "pakiet nr 1” z 250 tys. dolarów oraz awizował przekazanie "pakietu $\mathrm{nr} 2$ ” z identyczną kwotą sześć dni później. ${ }^{86}$ Komar potwierdził odbiór „pakietu nr 1” już 7 maja $^{87}$, a kolejnego 15 maja tr. $^{88}$

Desygnowanie Nowickiego do Francji było zapewne dla Tatara niewygodne, ale konieczne ${ }^{89}$ Gdy chciał sam pojechać, okazało się, że są trudności z wyrobieniem mu wizy - donosił o tym Chojecki Komarowi trzy tygodnie wcześniej..$^{90}$ Nie wiadomo, czy komunistyczny wywiad maczał w tym palce, ale sprawa musiała być rzeczywiście poważna, skoro zdecydował się - po miesiącach kluczenia i grania na zwłokę - na rozpoczęcie akcji oddawania pieniędzy i to poprzez człowieka, któremu co najmniej nie ufał. Tatar zapewne nie dopuścił Nowickiego do skrytek, lecz dostarczał gotówkę poprzez Woydata lub kogoś innego z zaufanego personelu. 20 maja $1948 \mathrm{r}$. Krajewski otrzymał „pakiet nr 6” z kwotą 250 tys. dolarów, a w tym samym czasie Chojeckiemu dostarczono w Londynie 150 tys. dolarów. ${ }^{91} 27$ maja Chojecki meldował, że Nowicki jest już w Londynie i że ostatni pakiet paryski z 250 tys. dolarów wyszedł, a „Drawa” została w całości przekazana ${ }^{92}$ - ostatni „pakiet nr 21” (150 tys. dolarów) dostarczył osobiście Nowicki do Pragi tamtejszemu attaché wojskowemu płk. dypl. Ignacemu Bukowskiemu ${ }^{93}$

${ }^{86}$ AIPN, SWSW, 2306/13909/2, Depesza szyfrowa Maksymiliana Chojeckiego do Wacława Komara, b.m., 7 V 1948 r., 372.

87 Ibid., Depesza szyfrowa Wacława Komara do Maksymiliana Chojeckiego, nr 620, b.m., 7 V 1948 r., 374.

88 Ibid., Depesza szyfrowa Wacława Komara do Maksymiliana Chojeckiego, b.m., 15 V 1948 r., 376.

89 Ibid., Depesza szyfrowa Maksymiliana Chojeckiego do Wacława Komara, b.m., 19 V 1948 r., 380. 20 V 1948 r. Nowicki miał wrócić z Paryża (ostatecznie Komar polecił zostać mu dłużej i wrócił tydzień później), a Chojecki już był umówiony z Tatarem na rozmowę o kolejnych ekspedycjach gotówki z Paryża.

90 Ibid., Pismo płk. Maksymiliana Chojeckiego do gen. Wacława Komara, nr 00173/48, b.m., 22 IV 1948 r., 356, 357.

91 Ibid., Depesza szyfrowa Maksymiliana Chojeckiego do Wacława Komara, b.m., 20 V 1948 r., 382.

92 Ibid., Depesza szyfrowa Maksymiliana Chojeckiego do Wacława Komara, b.m., 27 V 1948 r., 388.

93 Ignacy Bukowski (ur. 12 XII 1901 - zm. 29 VII 1984) - płk dypl. IWP (1948), oficer dyplomowany artylerii WP - ukończył francuską École Supérieure de Guerre (1933-1935); po wyjściu z niewoli był oficerem Polskiej Misji Wojskowej w Berlinie (1945-1947), następnie służył w Oddziale II SG jako attaché wojskowy w Pradze (1947-1948) i w Paryżu (1948-1950) oraz w Biurze Studiów Wojennych przy MON na stanowisku zastępcy szefa (1950-1951); w 1951 r. zwolniony z wojska, a w roku następnym aresztowany przez GZI w areszcie przebywał do grudnia 1954 r.; po wyjściu z aresztu (nigdy nie został prawomocnie 
4 czerwca 1948 r. ${ }^{94} \mathrm{~W}$ liście do Spychalskiego z 2 czerwca Tatar stwierdził, że w 21 „pakietach” przekazano wcześniej wskazywaną kwotę 2247362 dolarów; ponadto przypominał się Spychalskiemu w sprawie krajowej „fundacji” oraz swojego przyjazdu do Polski. ${ }^{95}$ Jeśli „Drawa” została zlikwidowana, to pozostało jednak sporo pieniędzy ulokowanych w nieruchomościach, a także gotówka z konta Polish Self-Help Association oraz zapewne inne kwoty głębiej „zamelinowane” przez Tatara.

Wraz z przekazaniem właściwej części funduszu dolarowego Tatar rozpoczął przygotowania do łagodnego transferu z emigracji do kraju. 2 czerwca 1948 r. Nowicki donosił Komarowi, że Tatar wraz z gen. bryg. Jerzym Kirchmayerem i płk. dypl. Kazimierzem Plutą-Czachowskim organizują "fundację" na terenie kraju, która ma wspierać byłych żołnierzy AK m.in. poprzez tworzenie rolniczych warsztatów, rozszerzenie działalności bursy im. Grota-Roweckiego na warszawskim Żoliborzu czy też założenie ośrodka zdrowia, którym miał kierować dr Szymon Wacek. Symbolicznym zamknięciem sprawy funduszu „Drawa” (a przynajmniej jego zasadniczej części) były nagrody, jakie spłynęły na członków Komitetu Trzech - a te nie były szczególnie wyszukane. 4 czerwca 1948 r. Komar depeszował do Chojeckiego z pytaniem, jakie odznaczenia i jakiej klasy posiadają Tatar, Utnik i Nowicki. ${ }^{96} \mathrm{~W}$ lipcu Tatar został odznaczony Orderem Odrodzenia Polski

skazany) do wojska nie wrócił i w latach 1956-1962 pracował jako redaktor w Wydawnictwie „Wiedza Powszechna”, a od 1963 r. był dyrektorem Biura Turystyki Zagranicznej „Gromada" w Warszawie; 30 IV 1964 r. został przywrócony do służby w Zarządzie II SG i skierowany do Międzynarodowej Komisji Nadzoru i Kontroli w Wietnamie jako zastępca Sekretarza Generalnego ds. Wolnościowych - na tym stanowisku służył od 4 V 1964 r. do $31 \mathrm{~V}$ 1965 r.; o dalszym wykorzystaniu w wywiadzie nie wiadomo; zob. AIPN, MON, 2174/8291, TAP Ignacego Bukowskiego; Zarząd II SG, 2602/9181, TAP Ignacego Bukowskiego; zob. także Koreś, „Studium uwikłania. Życie i kariera attaché wojskowego w Pradze i Paryżu płk. dypl. Ignacego Bukowskiego (1904-1984)," w Attaches i przedstawiciele Misji Wojskowych w Wojsku Polskim II RP i Siłach Zbrojnych PRL, red. Bartosz Kapuściak (Katowice-Warszawa: Instytut Pamięci Narodowej, 2021), w druku.

94 AIPN, SWSW, 2306/13909/2, Depesza szyfrowa Wacława Komara do Maksymiliana Chojeckiego, nr 772, b.m., 31 V 1948 r., 390; Depesza szyfrowa Maksymiliana Chojeckiego do Wacława Komara, b.m., 2 VI 1948 r., 395. Zachowana korespondencja nie obejmuje wiadomości o przekazywaniu „pakietów” o nr.: 3-5, 7-10, 15-20.

95 Ibid., List gen. Stanisława Tatara do gen. dyw. Mariana Spychalskiego (przez gen. Wacława Komara), odpis, b.m., 2 VI 1948 r., 397. Trochę inne obliczenia podał Komar w raporcie dla Spychalskiego z 12 VII 1948 r.: 1/ wpłaty do Ambasady w Londynie obliczał na 148600 dolarów; 2/ pieniądze przeznaczone na zakupy, a wydane w Paryżu obliczał na 374404 dolary; 3/ przerzuty kurierskie wynosić miały 360 tys. dolarów; 4/ wpłaty po 24 IV $1948 \mathrm{r}$. z Belgii, Francji i Londynu wynosić miały 1295212 dolarów; łączna kwota była obliczona na 2178214 dolarów; zob. Bagieński, Wywiad, 2:20.

96 AIPN, SWSW, 2306/13909/2, Depesza szyfrowa Wacława Komara do Maksymiliana Chojeckiego, nr 828, b.m., 4 VI 1948 r., 400. 
kl. 3, ${ }^{97}$ Nowicki analogicznym orderem tyle, że kl. $4,{ }^{98}$ a najwięcej „zyskał” Utnik, otrzymując awans na pułkownika. ${ }^{99}$ Polska Ludowa $z$ dystansem potraktowała członków Komitetu, niewielkim kosztem zyskując silny zastrzyk dewizowy.

Przekazanie kwoty ponad 2,2 mln dolarów nie zamknęło jednak tematu posiadanych przez Tatara aktywów - a te ciągle były niemałe. Do sumy tej należy przede wszystkim dodać kwoty, jakie wydatkowano w latach 19471949, zgodnie z dyspozycjami płynącymi z Warszawy, ${ }^{100} 10$ września $1948 \mathrm{r}$. na posiedzeniu Komitetu Trzech zaprotokołowano, że rząd polski zlecił im zakupy (realizował je przede wszystkim Utnik) na łączną kwotę 606 tys. dolarów, na które otrzymano z Warszawy około 367 tys. dolarów - nie wiadomo, czy chodziło o pieniądze z "Drawy” - a brakowało do zamknięcia rachunków około 238 tys. dolarów. Z tej kwoty 161 tys. dolarów miało pochodzić z pieniędzy zgromadzonych na koncie londyńskiej „fundacji” Polish Self-Help Association. ${ }^{101}$

23 czerwca 1948 r. Tatar wyleciał z Londynu do Warszawy ${ }^{102}$ - przy okazji wynikło zamieszanie, gdyż zgodę na wyjazd przekazał mu Nowic-

\footnotetext{
97 Ibid., 2386/13888, Wniosek na odznaczenie gen. bryg. Stanisława Tatara Orderem Polonia Restituta III kl. podpisany przez szefa Oddziału II SG gen. bryg. Wacława Komara, b.m., [1948], 297.

98 Ibid., 2386/13865, Wniosek na odznaczenie płk. dypl. Stanisława Nowickiego Orderem Polonia Restituta IV kl. podpisany przez szefa Oddziału II SG gen. bryg. Wacława Komara, b.m., [1948], 123; CAW-WBH, TAP, 742/61/1284, TAP Stanisława Nowickiego, Zeszyt ewidencyjny S[tanisława] Nowickiego, b.m., 28 VI 1956 r., b.p.; w teczce akt personalnych brak informacji o nadaniu powyższego odznaczenia.
}

99 AIPN, SWSW, 2386/13897, Wniosek awansowy na nadanie stopnia pułkownika podpułkownikowi Marianowi Utnikowi podpisany przez szefa Oddziału II SG gen. bryg. Wacława Komara, b.m., [1948], 181; Zarządzenie Prezydenta RP o mianowaniu 10 VII 1948 r. Mariana Utnika pułkownikiem podpisane przez prezydenta RP Bolesława Bieruta i ministra obrony narodowej marsz. Michała Rolę-Żymierskiego, b.m., 183; na zarządzeniu odręczna adnotacja Roli-Żymierskiego: „Mieć w ewidencji, jednak nie ogłaszać. Zaświadczenie płk. Utnikowi wydać, 19 VII 1948 r."; CAW-WBH, TAP, 1268/67/301, TAP Mariana Utnika, Zeszyt ewidencyjny Mariana Utnika, b.m., 3 VI 1957 r., b.p.

100 Jest to zupełnie odrębny temat, posiadający obszerną dokumentację i wymagający indywidualnego potraktowania.

101 AIPN, SWSW, 2306/13909/2, Protokół uchwał Komitetu „Fundacji” z 10 IX 1948 r., b.m., 403.

102 Druga wizyta Tatara w Polsce w czerwcu 1948 r. była także początkiem jego inwigilacji przez GZI WP - co ciekawe, doniesienie do kontrwywiadu złożyło kierownictwo Oddziału II SG; wywiad informował, że Tatar kontaktuje się na terenie kraju z oficerem służby czynnej, swoim powinowatym, mjr. Władysławem Romanem, pracownikiem Sztabu Generalnego, „co do którego istnieją pewne poszlaki, że «T» może go wykorzystać do pracy na korzyść obcego wywiadu”; zob. ibid., 2386/13888, [płk Ireneusz Krzemień, szef Oddziału II GZI WP] Informacja specjalna dotycząca rozpracowania gen. Tatara Stanisława i jego kontaktów, b.m., b.d. i nr kanc., 6-9. Najprawdopodobniej to właśnie podczas tej wizyty, po 
ki, ${ }^{103}$ co z kolei zaniepokoiło Komara, czy przy okazji jego agent się nie zdemaskował i dlatego dopytywał się gwałtownie, czy Nowicki: „przedstawił sprawę przyjazdu [...] jako moje polecenie bezpośrednie, czy też jako polecenie otrzymane przez swego łącznika". ${ }^{104}$ Przy okazji tej wizyty jego "aniołem stróżem” został wyznaczony por. Aleksander Kurinia z Oddziału II, który pozostawił obszerne zapisy aktywności Tatara. ${ }^{105}$ Jego wyjazd nasilił presję ze strony Nowickiego i Utnika na Komara, ażeby zastopował jego działalność krajową, a szczególnie zwalczali pomysł krajowej „fundacji”, z naciskiem na torpedowanie zgody na pozostawienie jej jakichkolwiek zagranicznych aktywów. Donosili także - tym razem poprzez łączność attachatu i w konsultacji z Chojeckim ${ }^{106}$ - że Tatar przywiezie ze sobą kolejne 100 tys. dolarów z Paryża; były to kwoty, które Tatar miał „zamelinowane" w zupełnie im nieznanych miejscach. ${ }^{107}$ Wkrótce Komar potwierdził, że

raz pierwszy, zaczęto nagrywać na taśmę rozmowy Tatara z Komarem (nagrywano także rozmowy z Nowickim i Utnikiem). Lektura stenogramów z taśm podsłuchowych, z rozmów, które odbywały się w luźnej, prywatnej atmosferze, jest porażającym dowodem spoufalania się Tatara (et consortes) z szefem komunistycznego wywiadu; odsłania także prawdziwe intencje Tatara i jego wspólników, „ustawiających się” w nowej rzeczywistości (przykładowo zob. AIPN, Zarząd II SG, 2602/483, [Stenogram rozmowy Stanisława Tatara z Wacławem Komarem z końca czerwca lub początku lipca 1948 r.], b.m., 98 i n., w tej rozmowie mowa jest m.in. o odznaczeniu Tatara Orderem Odrodzenie Polski, co pozwala ją właśnie tak datować; inne zapisy często nie mają podobnych punktów zaczepienia i trudno je konkretnie umieścić w czasie).

103 AIPN, SWSW, 2306/13909/2, Depesza szyfrowa Maksymiliana Chojeckiego do Wacława Komara, b.m., 17 VI 1948 r., 407.

104 Ibid., Depesza szyfrowa Wacława Komara do Maksymiliana Chojeckiego, nr 1027, b.m., 18 VI 1948 r., 409.

105 Zob. AIPN, MSW, 0192/760/24, cz. 2, Raport kpt. Aleksandra Kurinia [o pobycie Tatara w Polsce w 1948 r.] dla zastępcy szefa GZI płk. Antoniego Skulbaszewskiego, Warszawa, 23 XII 1950 r., 295-297 (w teczce tej znajdują się także zeszyty z odręcznymi notatkami Kurinii). Aleksander Kurinia (ur. 31 VIII 1920 - zm. 10 II 2015) - awansował do stopnia pułkownika i był później m.in. attaché wojskowym w Belgradzie.

106 To dowód na to, że Komar zdecydował się powiązać działania swojego agenta (Nowickiego) i współpracującego z nim wówczas - taktycznie, jak się okaże - Utnika z oficjalnym aparatem Oddziału II w Londynie. Oczywiście nie był to objaw finezji operacyjnej, która wskazywałaby raczej na utrzymywanie swojej agentury w niewiedzy o sobie, a raczej potwierdzenie działań nastawionych na krótkoterminowy efekt - czyli wydobycie ostatniego dolara ze skrytek Tatara.

107 Attaché także uspokoił szefa wywiadu, że Nowicki przekazał polecenie wyjazdu jakoby poinformowany przez łącznika z Warszawy. Ponadto informował - na podstawie doniesień Nowickiego i Utnika - że Tatar ma dwie koncepcje likwidacji swoich spraw: pierwsza obejmowała projekt pozostawienia inwestycji zagranicznych (farma w Wlk. Brytanii i posiadłość we Francji, plus domy w Londynie, Paryżu i Brukseli) jako zabezpieczenia finansowania krajowej „fundacji” (była to w ich opinii koncepcja, z oczywistych powodów, wiodąca); druga, skromniejsza, miała być zaproponowana, gdyby nie było zgody na pierwszą i miała 
Tatar przekazał mu... 200 tys. dolarów, co go sprowokowało do polecenia przysłania kolejnych kwot. Jeśli Tatar liczył, że w ten sposób spacyfikował szefa komunistycznego wywiadu, to się mylił - wzmógł tylko jego nieufność i utwierdził go w przekonaniu, że przewodniczący Komitetu Trzech dysponuje jeszcze całkiem poważnymi kwotami, których nie chce ujawnić. Z kolejnego doniesienia Nowickiego z 29 czerwca 1948 r. wynika, że Komar wręcz polecił znalezienie i zajęcie pieniędzy „zamelinowanych” przez Tatara w Paryżu, właśnie korzystając z jego obecności w Warszawie. Utnik i Nowicki odżegnali się jednak od tego pomysłu, twierdząc, że sprawa ma niewielkie szanse powodzenia i może spowodować odizolowanie ich od Tatara, a być może zmusi go do pełnego zawieszenia relacji i „zerwania się" z kontaktów z Warszawą. ${ }^{108}$ Nie zdobyli się na otwarte wystąpienie przeciwko Tatarowi, choć 14 lipca 1948 r. donosili o „buncie” jego personelu przeciwko Woydatowi, ${ }^{109}$ który Tatar łagodził telefonicznie, obiecując sprawę załatwić w drodze powrotnej z Warszawy (via Paryż) - w związku z tym wnioskowali, żeby uniemożliwić mu powrót przez Francję. ${ }^{110}$

15 lipca 1948 r. Utnik wprost zwrócił się do Komara z prośbą o przeniesienie do pracy w kraju - nie wytrzymywał już stałego napięcia nerwowego i być może obawiał się Tatara. ${ }^{111}$ W ślad za nim list do Komara wysłał Nowicki, który jednak w kontrze do Utnika sugerował, że wyjazd do kraju powinien nastąpić dopiero po pełnej likwidacji spraw związanych z „Drawą, żeby nie pozostawić

obejmować likwidację inwestycji zagranicznych i prowadzenie działalności „fundacji” tylko w kraju (AIPN, MBP, 0192/760/24, cz. 2, Depesza szyfrowa Maksymiliana Chojeckiego do Wacława Komara, b.m., 19 VI 1948 r., 411, 412).

108 AIPN, SWSW, 2306/13909/2, Depesza szyfrowa Maksymiliana Chojeckiego do Wacława Komara, b.m., 29 VI 1948, 416.

109 Ibid., List do Stanisława Tatara od Władysława Garlickiego, Jana Majeranowskiego i Janiny Pronaszko, Paryż, 20 VI 1948 r., 451. List ten jest niezwykle ważnym świadectwem rozchodzenia się wizji, jaką Tatar roztaczał przed swoim personelem we Francji (np. współwłasność majątku, który dotąd był tylko administrowany przez podpisanych, czy też etos pracy „dla sprawy”, a nie dla zysku), a rzeczywistością, którą reprezentował Woydat, który lekceważył podległy mu personel i był jedynym plenipotentem praw majątkowych: „Skupienie praw własności obydwu obiektów w jednym ręku (w dodatku osoby spowinowaconej z Panem Generałem) jest niebezpieczne ze względów prawnych, niemoralne ze względów ideologicznych, powoduje dyktaturę, a w razie nieszczęśliwego wypadku Prezesa [Woydata D. K.] może spowodować olbrzymie komplikacje prawne i niebezpieczeństwo dla Funduszu, łącznie do straty obiektów". Wyraźnie wyziera z tego listu janusowe oblicze Tatara, rzutujące poważnie na przedstawianej po latach wersji, że jego intencje zawsze były czyste i tylko „złe języki” oskarżały go o prywatę i chęć ustawienia się.

110 Ibid., [Raport poufny Stanisława Nowickiego dla Wacława Komara], b.m., 14 VII 1948 r., 419.

111 Ibid., List Mariana Utnika do Wacława Komara - prośba o przydzielenie do pracy w kraju, b.m., 15 VII 1948 r., 426. 
ich właśnie w ręku wspomnianego Tatara. ${ }^{112}$ Tarcia wewnątrz Komitetu Trzech dzieliły już wszystkich jego członków, ale Warszawa nie zamierzała zadbać zbytnio o ich pogarszający się komfort psychiczny i dalej zalecała im pracę za granicą z zadaniem neutralizowania Tatara. Jednak list Nowickiego na tyle zaniepokoił Komara, że postanowił spotkać się z nim w Pradze, a i Utnik miał otrzymać dowód życzliwości ze strony centrali. ${ }^{113}$

Pokrzepieni i zainspirowani do dalszych wysiłków ${ }^{114}$ Utnik i Nowicki kontynuowali swój „trud” pracy agencyjnej. 23 sierpnia 1948 r. donosili, że ich agent we Francji „Mar” (Majeranowski) zbliżył się do administrujących częścią funduszu dolarowego przejętego przez PSZ w 1946 r. płk. dypl. Janusza Bokszczanina i ppłk. dypl. Jana Kamieńskiego; rola Bokszczanina $\mathrm{w}$ tym procederze jest ciągle niewiadomą i do identyfikowania go z działaniami Kamieńskiego należy podchodzić ostrożnie. Z raportu wynika, że w ramach operacji „Sen” mieli dotrzeć przede wszystkim do Kamieńskiego (choć „Mar” o tym nie wiedział, gdyż mu nie do końca ufano), a docelowo przejąć jego fundusze. Sugerowali próbę dogadania się z nim na takich zasadach, jak to załatwiono z Komitetem Trzech, a do rozmów z Bokszczaninem proponowali wysłać Tatara, którego łączyły z nim „do końca dobre stosunki [...] na którego zawsze miał spory wpływ". Ponadto obciążyli swojego przełożonego winą za utratę tego fragmentu „Drawy”, który w 1946 r. na terenie Niemiec przejęła armia i który oddano do administrowania Kamieńskiemu - pokrótce wyłuszczyli Komarowi, jak doszło do przekazania Kopańskiemu „Z winy Tatara, tych pieniędzy”. ${ }^{115}$ Wydaje się pewnym, że bez donosów Utnika i Nowickiego na Tatara późniejsza wiedza funkcjonariuszy bezpieki i GZI na temat jego działalności byłaby znacznie uboższa, co później przełożyło się na efektywność śledztwa w sprawie TUN.

\footnotetext{
112 Ibid., List Stanisława Nowickiego do Wacława Komara, b.m., 14 VII 1948 r., 429, 430.

113 Ibid., Depesza Wacława Komara do Maksymiliana Chojeckiego, b.m., 17 VII 1948 r., 432. Nowicki został na 23 VII 1948 r. wezwany do Pragi, a Chojecki miał, jak najszybciej, dotrzeć do Warszawy. Attaché wyleciał 20 VII tr., Nowicki wkrótce po nim (ibid., Depesza Maksymiliana Chojeckiego do Wacława Komara, b.m., 19 VII 1948 r., 434). Także Utnik miał zostać udobruchany możliwością wyjazdu do Polski, ale nie otrzymał wizy (ibid., Depesza Maksymiliana Chojeckiego do Wacława Komara, b.m., 7 VIII 1948 r., 438); zrekompensowano mu to, wysyłając do Londynu jego córkę (ibid., Depesza Wacława Komara do Maksymiliana Chojeckiego, b.m., 14 VIII 1948 r., 440).

114 Nowicki do praktycznie samego końca swojej „współpracy” z Komarem żalił się w raportach, że mógłby otrzymywać z centrali precyzyjne instrukcje do działania, gdyż działał "po omacku”. Ten syndrom „osamotnienia agenta w terenie” to domaganie się większej uwagi i w sumie brak reakcji ze strony Komara można odebrać dwojako - albo jako formę braku zainteresowania dalszą współpracą i krótkoterminową perspektywę współpracy (do zakończenia likwidacji „Drawy"), albo jako brak profesjonalizmu ze strony szefa komunistycznego wywiadu.

115 AIPN, SWSW, 2306/13909/2, [Raport poufny Stanisława Nowickiego dla Wacława Komara], b.m., 23 VIII 1948 r., 442-444.
} 
23 lipca 1948 r., w czasie spotkania w Pradze, szef wywiadu polecił Nowickiemu rozpoczęcie ostatniej fazy likwidacji działalności Komitetu Trzech - zwinięcie inwestycji. ${ }^{116}$ Precyzyjne dyspozycje miał przywieźć z Warszawy Tatar, który wyjechał z Polski 5 sierpnia i następnie na miesiąc pojechał do Paryża; do Londynu wrócił pomiędzy 3 a 5 września. W kolejnym donosie, na podstawie raportu „Mara”, przekazano Komarowi, że w konflikcie pomiędzy personelem a Woydatem Tatar stanął po stronie tego ostatniego, co było do przewidzenia ze względu na łączące ich więzi rodzinne. Tatar rozpoczął likwidację spraw we Francji, wypłacając pierwsze zaliczki (na poczet odprawy) swojemu personelowi (np. „Mar” otrzymał 500 dolarów i 100 tys. franków francuskich). W Paryżu dowiedział się, że Kamieński zakonspirował się tak głęboko, że nawet $\mathrm{z}$ Bokszczaninem kontaktował się za pośrednictwem skrzynki pocztowej. Bokszczanin powiedział mu, że „Cozasa” próbują odnaleźć m.in. ludzie związani z gen. bryg. Tadeuszem Pełczyńskim i francuska policja. Tatar po powrocie do Londynu twierdził, że w Warszawie ustalił ostateczną likwidację inwestycji Komitetu na jesień 1949 r. - Nowicki jednak otrzymał w Pradze zupełnie inne dyspozycje. Na podstawie tego Utnik i Nowicki uznali, że Tatar planuje wykorzystać nadchodzący rok na tworzenie niezależnych „czarnych funduszy”, których nie przekaże do kraju. ${ }^{17}$ Dalsze meldunki o Tatarze miał Nowicki przedłożyć osobiście, gdyż 7 października 1948 r. miał wypłynąć do Polski na pokładzie statku „Lech”."118 Ostatecznie jednak wyruszył dzień później statkiem „Lublin”, a do Gdyni dotarł 12 października. ${ }^{119}$ Wiózł ze sobą 120 tys. dolarów. Z kraju wyruszył w drogę powrotną do Wlk. Brytanii 30 października.

W notatce z 8 września 1948 r. Utnik i Nowicki streścili szefowi Oddziału II ustalenia, jakie miał Tatar wynegocjować (wg jego przekazu) w czasie swojej ostatniej bytności w Warszawie i rozmów z Komarem i Spychalskim. ${ }^{120}$ Najważniejsze dotyczyły zgody na przeniesienie działalności „fundacji” (Polish Self-Help Association) na teren kraju, gdzie miała ona otrzymać nowy zarząd - określany jako „kuratorium” (przy prezesurze Tatara) - w składzie: gen. dyw. Franciszek Jóźwiak „Witold” (komendant główny

116 Ibid., List Stanisława Nowickiego do Wacława Komara, b.m., 23 VIII 1948 r., 440. Nowicki prosił o rozpoczęcie likwidacji od wizyty w kraju, którą planował na październik tr.; miał zamiar wywieźć z Londynu córkę (jeden z powodów tego posunięcia wyjdzie na jaw w następnym roku) oraz własny dobytek - łącznie z samochodem osobowym.

117 Ibid., [Raport poufny Stanisława Nowickiego dla Wacława Komara], b.m., 9 IX 1948 r., $448-450$.

118 Ibid., Depesza szyfrowa Maksymiliana Chojeckiego do Wacława Komara, nr 2597, b.m., 29 IX 1944 r., 466.

119 Ibid., Depesza szyfrowa Maksymiliana Chojeckiego do Wacława Komara, b.m., 7 X 1948 r., 472.

120 Było to nic innego, jak protokół rozbieżności, mający udowodnić brak szczerości Tatara. 
Milicji Obywatelskiej, wiceminister bezpieczeństwa publicznego, członek Biura Politycznego KC PZPR), gen. bryg. Kirchmayer, płk dypl. Pluta-Czachowski. Szczególnie ciekawie brzmi informacja o włączeniu tow. „Witolda” do planowanego zarządu - być może miał on z ramienia partii kontrolować działalność „fundacji”, choć obecnie brak jest danych potwierdzających rolę, jaką miał odegrać. Głównym projektem „fundacji” miała być bursa im. Grota-Roweckiego z 200 pokojami dla młodzieży uczącej się (na ten projekt miała „fundacja” wyłożyć 350 tys. dolarów - to pokazuje, jakimi kwotami Tatar jeszcze dysponował po oddaniu „Drawy”) plus inwestycje na terenie Warszawy, m.in. zakup autobusów we Francji czy sprzętu dla Zakładu Oczyszczania Miasta. Tatar miał także wynegocjować warunki rozliczenia swojego personelu we Francji, który także miał otrzymać możliwość powrotu do kraju (dobrowolnego) oraz odprawy pieniężne. Tatar twierdził, że z 200 tys. dolarów, które przywiózł do Warszawy, 50 tys. miał zachować na odprawy. Pozostałe kwoty dolarowe miał przekazywać kanałem wojskowym do Oddziału II SG IWP, z tym, że dolary miały być przeliczane na złotówki (wg tzw. „kursu uprzywilejowanego”). Liczył przy tym, że w grudniu $1948 \mathrm{r}$. przeniesie się na stałe do kraju, skąd będzie wyjeżdżał za granicę dla dokończenia spraw likwidacyjnych. ${ }^{121}$ A „Drawa” - wówczas już coraz częściej określana mianem funduszu "fundacji” - dalej „cudownie” pączkowała. Między 14 a 21 października 1948 r. Woydat miał przekazać attaché wojskowemu w Paryżu ppłk. Krajewskiemu trzy „pakiety” zawierające 330 tys. dolarów ${ }^{122}$ - ostatecznie najpierw przekazał "pakiet” zawierający 200 tys. ${ }^{123}$, dopiero około 9 listopada kolejne 130 tys. dolarów; miał też doręczyć 10 tys. „W metalu” (chodziło o dolary w złocie). ${ }^{124} 25$ października Nowicki dostarczył do attachatu dwa kolejne „pakiety”, w których znajdowało się: 120 tys. i 47045 dolarów. ${ }^{125}$

15 września 1948 r. Nowicki i Utnik raportowali na podstawie relacji „Mara”, który przyjechał do Londynu, m.in. że był on we Francji zarządcą posiadłości ziemskiej Château de Presles-en-Brie zakupionej przez Tatara,

121 AIPN, SWSW, 2306/13909/2, [Stanisław Nowicki] Notatka - skonkretyzowanie rozmów przeprowadzonych przez gen. Stanisława Tatara w lipcu i sierpniu 1948 r. z czynnikami oficjalnymi w Warszawie w sprawie funduszów tzw. „Drawy” i „Fundacji” - wg referatu gen. Tatara przedstawionego na plenum „Komitetu Drawa” w Londynie 7 IX 1948 r., b.m., 8 IX 1948 r., 452-454.

122 Ibid., Depesza szyfrowa Maksymiliana Chojeckiego do Wacława Komara, nr 2654, b.m., 5 X 1948 r., 468.

123 Ibid., Depesza szyfrowa Wacława Komara do Maksymiliana Chojeckiego, b.m., 20 X 1948 r., 482.

124 Ibid., Depesza szyfrowa Wacława Komara do Maksymiliana Chojeckiego, b.m., 9 XI 1948 r., 488.

125 Ibid., Depesza szyfrowa Maksymiliana Chojeckiego do Wacława Komara, b.m., 25 X 1948 r., 480. 
której właścicielem - przynajmniej formalnie - był Woydat, leżącej w Departamencie Seine-et-Marne (ok. $30 \mathrm{~km}$ na płd. od Paryża). Do pomocy „Marowi” Tatar zatrudnił inż. rolnika Parowskiego, który wcześniej pracował na posiadłości... Kamieńskiego. W Presles zainwestowano 35 tys. dolarów. Stałą rezydentką Presles miała być Anna Anders-Romanowska, córka gen. Andersa, oraz jej mąż rtm. Jan Romanowski. ${ }^{126} 10$ września „Mar” formalnie przekazał zarząd Preseles Janinie Pronaszko. ${ }^{127}$ Podpułkownik Władysław Garlicki ps. „Bogumił” był zarządcą kamienicy przy Rue de Lauriston 74, która wkrótce miała być przekazana na własność państwa ${ }^{128}$ obecnie jest to siedziba Stacji Naukowej Polskiej Akademii Nauk w Paryżu.

W ramach akcji „Sen” Majeranowski ustalił, że Kamieński „Cozas” jest właścicielem dużej posiadłości ziemskiej Château de Cussac, o powierzchni 30 ha, wraz z winnicami, leżącej w słynnym rejonie winiarskim Medoc (ok. $50 \mathrm{~km}$ od Bordeaux). Informacje takie wykorzystywano następnie w czasie prowadzenia działań operacyjnych wobec Kamieńskiego i Bokszczanina. Majeranowski zacytował też słowa Tatara, jakie kilkanaście dni wcześniej skierował do niego oraz do Pronaszko i Garlickiego: „niech się wam nie zdaje, że na jedenastce [w domu przy Cornwall Gardens 11, czyli w kwaterze Nowickiego i Utnika w Londynie - D.K.] panuje zgoda. Nowicki po powrocie z Polski, to zupełnie inny człowiek «drugi Bierut», fałszywy, gorszy od Utnika. Radzę trzymać się z daleka od niego, bo możecie się wplątać w ładną kabałę". ${ }^{129}$ Pomiędzy członkami Komitetu Trzech otwarta wojna wisiała dosłownie na włosku.

W listopadzie 1948 r. do Paryża pojechał Utnik, który w ramach operacji „Sen” miał zwerbować do płatnej współpracy żonę byłego szefa Wydziału Finansowego Oddziału VI i członka zarządu „fundacji” ppłk. int. Franciszka Prohaski, Marię (Francuzka, z domu Muchape). Miała zareagować z entuzjazmem na tę propozycję, choć zapewne nie zdawała sobie sprawy do kogo miały trafiać jej raporty - najprawdopodobniej miała także śledzić działania Tatara i jego zaufanego personelu na terenie Francji. ${ }^{130}$ Wizyta Utnika w Pa-

126 Jan Władysław Romanowski (ur. 12 I 1916 - zm. 31 V 1997) - rtm. PSZ (1945), adiutant szefa Sztabu Armii Polskiej w ZSRS płk. dypl. Leopolda Okulickiego (1941), następnie gen. bryg. Zygmunta Szyszko-Bohusza (1942), a w końcu 1943 r. został osobistym adiutantem dowódcy 2 Korpusu Polskiego; od 1957 r. do śmierci mieszkał w Kanadzie.

127 AIPN, SWSW, 2306/13909/2, Protokół zdawczo-odbiorczy kasowości i administracji posiadłości Château de Presles-en-Brie. Zdający p. Jan Majeranowski, odbierająca p. Janina Pronaszko. Protokół został sporządzony w obecności właściciela p. Zdzisława Woydata, b.m., 10 IX 1948 r., 497.

128 Ibid., [Raport poufny Stanisława Nowickiego dla Wacława Komara], b.m., 15 IX 1948, 456, 457.

129 Ibid., 457.

130 Ibid., [Raport poufny Stanisława Nowickiego dla Wacława Komara], b.m., 29 XI 1948 r., 496. 
ryżu ujawniła dalsze, samodzielne i niekonsultowane $\mathrm{z}$ Warszawą działania Tatara na terenie Francji, m.in. wokół kamienicy przy Rue de Lauriston 74, gdzie chciał na trzy lata zainstalować Woydata, ponownie jako przedstawiciela YMCA; miał też podjąć jakieś zobowiązania wobec tej organizacji. ${ }^{131}$

Najbardziej jednak przykuwają uwagę informacje o siatce łączności z krajem, jaką miał zorganizować - wykorzystując drogę morską - ppłk dypl. Kamieński, przy pomocy m.in. cichociemnego, por. Zygmunta Gromnickiego ps. "Gul”, „Grom”, który mieszkał w Gdyni; sugerowano, że Gromnicki może być współpracownikiem wywiadu francuskiego i oczywiście Komar był o wszystkim informowany. ${ }^{132}$ Powstają pytania, czy Nowicki i Utnik, którzy wciągnęli do współpracy byłych podkomendnych: Majeranowskiego i mjr. dypl. Krzyżanowskiego oraz żonę ppłk. Prohaski, byli świadomi, że ich działania mogą nieść za sobą fatalne konsekwencje dla byłych żołnierzy PSZ mieszkających w kraju? Że narażają także tych, którzy mieszkają za granicą? Czy ich desperacja była aż tak wielka, że musieli przekroczyć kolejną granicę, przeistaczając się $\mathrm{z}$ defraudantów $\mathrm{w}$ płatnych renegatów? $\mathrm{Z}$ obrazu, jaki wyłania się $\mathrm{z}$ dokumentów, wynika, że chcąc się wyplątać z krępującej ich współpracy z Tatarem, wpadli w jeszcze większe sidła, zastawione przez Komara. Brnęli w nie, pchani siłą inercji, wikłając się w coraz bardziej ścisłą - i zupełnie świadomą - współpracę z systemem, który generalnie gardził tak nimi, jak i tymi, których dla niego inwigilowali. W tym czasie Tatar odmówił przekazania wysłannikom Warszawy 10 tys. dolarów w złocie, które chciał zatrzymać jako rezerwę, ${ }^{133}$ a Kutin otrzymał od Woydata tylko 200 tys. fr. belgijskich ${ }^{134}$ (choć miał dostać 100 tys. dolarów), co zostało potwierdzone 13 grudnia 1948 r. (kwota wzrosła do 240 tys. fr. belgijskich $)^{135}$.

131 Ibid., Pismo płk. Maksymiliana Chojeckiego do gen. Wacława Komara, nr 00861/48, b.m., 9 XII 1948 r., 499-501; [płk dypl. Stanisław Nowicki] Notatka w sprawie usterek paryskich, b.m., 2 XII 1948 r., 503. Dokument ten przygotował Nowicki po konferencji Komitetu Trzech z 2 XII tr., w trakcie której Tatar złożył wyjaśnienia w sprawie swoich decyzji i zobowiązań wobec paryskiego majątku „Drawy”.

132 Ibid., [Raport poufny Stanisława Nowickiego dla Wacława Komara], b.m., 24 XI 1948 r., 492; List Jana Majeranowskiego [„Marek”] do Stanisława Nowickiego [„Norwich”], b.m., 15 XI 1948 r., 493, 494.

133 Ibid., [płk dypl. Stanisław Nowicki] Notatka w sprawie usterek paryskich, b.m., 2 XII 1948 r., 503. Tatar zobowiązał się do telefonicznego „uruchomienia” Woydata do uiszczenia Kutinowi kwoty 45904 dolarów na autobusy dla Warszawy.

134 Ibid., Attaché Wojskowy w Londynie [Maksymilian Chojecki] do szefa Oddziału II SG [Wacław Komar], Attaché Wojskowy przy Ambasadzie RP w Londynie, nr 00861/48, b.m., 9 XII 1948 r., 500, 501.

135 Ibid., Depesza szyfrowa Wacława Komara do Maksymiliana Chojeckiego, b.m., 13 XII 1948 r., 505. 
W końcu roku Tatar i jego podwładni znaleźli się praktycznie w stanie otwartego konfliktu. 9 grudnia 1948 r. Utnik i Nowicki zwrócili się do Komara o zgodę na formalne rozwiązanie Komitetu Trzech i usamodzielnienie się jej poszczególnych członków. ${ }^{136} \mathrm{~W}$ odpowiedzi z 24 grudnia szef komunistycznego wywiadu w zdecydowany sposób odrzucił tę supozycję: „Nie należy dopuścić do usamodzielnienia Tatara”. ${ }^{137}$ Równocześnie ciągle szły kolejne wpłaty: 20 grudnia Kutin otrzymał od Woydata 25340 dolarów. ${ }^{138}$

28 stycznia 1949 r. attaché wojskowy w Londynie ppłk Chojecki spotkał się z Tatarem dla omówienia spraw dotyczących likwidacji majątku Komitetu czynił mu przy tym wyrzuty, że nie dotrzymał zaplanowanych terminów. Był to ewidentny dowód na niecierpliwienie się Warszawy. Chojecki obiecał mu załatwienie wizy francuskiej - we Francji Tatar miał zakończyć likwidację tamtejszego majątku. Poinformował go także, że jego dom na Eallingu (wartości około 6 tys. funtów szterlingów) upatrzył sobie radca ambasady w Londynie, czasami też określany w dokumentach jako konsul generalny, Albert Morski (przy okazji także agent Oddziału II SG IWP o ps. „Dąbrowa”). ${ }^{139} \mathrm{~W}$ raporcie z 24 lutego 1949 r. Chojecki informował, że majątek we Francji znajdujący się pod kontrolą Tatara wyceniany jest na 250 tys. dolarów (nieruchomości), 50 tys. dolarów w gotówce i 10 tys. dolarów w złocie. Attaché informował, że Tatar miał wyjechać do Francji następnego dnia i przebywać tam do 20 marca, przy czym Chojecki radził ostrożność w przyciskaniu go do szybszej likwidacji majątku francuskiego, żeby go nie „spłoszyć”. Sugerował dać odpowiednie instrukcje ambasadorowi Putramentowi dla torpedowania ewentualnych zamierzeń Tatara. Chojecki wiedział już, że Tatar jest zaniepokojony aresztowaniami wśród akowców w kraju, a szczególnie martwił się losem swojego przyjaciela Pluty-Czachowskiego, który nie odpowiadał na kontakt z jego strony - w rzeczywistości Pluta znajdował się już od stycznia 1949 r. w areszcie MBP. Choć Chojecki sprawę zbagatelizował dla uspokojenia swego interlokutora, widział u niego wahanie, czy jest sens wracać do kraju. ${ }^{140}$ Warszawa nie miała jednak skrupułów i postanowiła się już nie patyczkować z Tatarem. Poprzez Putramenta postawiła mu, w ultymatywnej formie, żądanie przekazania kamienicy

136 Ibid., Referat Stanisława N.[owickiego], b.m., 9 XII 1948 r., 510, 511; Wniosek, b.m., b.d., 512.

137 Ibid., Depesza szyfrowa Wacława Komara do Maksymiliana Chojeckiego, b.m., 24 XII 1948 r., 514.

138 Ibid., Depesza szyfrowa Wacława Komara do Maksymiliana Chojeckiego, b.m., 20 XII 1948 r., 516.

139 Ibid., Pismo płk. Maksymiliana Chojeckiego do gen. Wacława Komara, nr 090/49, b.m., 31 I 1949 r., 518-520. „Dąbrowa” zdaje się nieprzypadkowo pojawił się wówczas w Londynie - stał się kolejnym elementem sieci zastawionej na Tatara.

140 Ibid., Pismo płk. Maksymiliana Chojeckiego do gen. Wacława Komara, nr 0164/49, b.m., 24 II 1949 r., 525-527. 
przy Rue de Lauriston 74 do 1 kwietnia 1949 r. ${ }^{141}$ I choć jeszcze w końcu lipca 1949 r. sprawa kamienicy nie była załatwiona, to zmuszono go do oddania 10 tys. dolarów w złocie („Kwituję odbiór trzech paczek metalu, które T. doręczył Bukowskiemu”). ${ }^{142}$ Tatar czuł, że jego pozycja wobec Warszawy staje się coraz słabsza. Osaczony i zdesperowany, mógł jeszcze próbować „urwać” się ze smyczy, którą dobrowolnie zgodził się założyć. A na horyzoncie pojawiły się kolejne problemy wynikające z ujawnienia sprawy „szafek” z walutą na terenie kraju.

W liście do Komara z 7 lutego 1949 r. Nowicki pisał m.in. o prowadzeniu z Tatarem rozgrywki, stwarzaniu mu problemów, żeby wywrzeć na niego presję oraz o załatwianiu wielu spraw w porozumieniu z Utnikiem, bez informowania Tatara. Ponadto Nowicki ponownie (po raz pierwszy zrobił to 15 grudnia 1948 r.) zabiegał o akceptację szefa komunistycznego wywiadu wojskowego dla ostatecznej likwidacji „Drawy” oraz możliwości wyjazdu do Polski, uzasadniając to tak: "praca w zespole, gdzie nie ma ani odrobiny wzajemnego zaufania, gdzie nic się nie wie, co drugi myśli i zamierza, ani nawet co robi, staje się bardzo niemiła, bo nie daje możliwości uchylenia się od współodpowiedzialności" ${ }^{143}$ Do listu dołączył notatkę (z 15 stycznia 1949 r.) o nieoficjalnych kanałach przerzutu pieniędzy z „Drawy” uruchomionych przez Tatara za plecami wywiadu - dzięki temu sprawa tzw. „szafek", które Tatar zorganizował w kraju, stała się formalnie znana wywiadowi wojskowemu. ${ }^{144}$ Zresztą informacje o „nielojalności” Tatara Komar miał już wcześniej, także od Nowickiego - czy to z jego meldunku ustnego złożonego w kraju w październiku, czy też z raportu z 15 grudnia $1948 \mathrm{r}^{145}$ Ów-

141 Ibid., Depesza szyfrowa Wacława Komara do Maksymiliana Chojeckiego, b.m., 3 III 1949 r., 529.

142 Ibid., Depesza szyfrowa Wacława Komara do Maksymiliana Chojeckiego, b.m., 28 III 1949 r., 531. W styczniu 1949 r. w Oddziale II obliczono, że dotąd Tatar et consortes przekazali łącznie 2942572 dolary, a to, co pozostało za granicą, oceniano na 615881 dolarów (przy czym w gotówce 223596 dolarów, reszta w nieruchomościach w Wlk. Brytanii i Francji), zob. AIPN, Zarząd II SG, 2602/473, [Wykaz środków przekazanych z funduszu „Drawa” i pozostałych za granicą], b.m., [1949], 19, 20.

143 AIPN, SWSW, 2306/13909/2, List Stanisława Nowickiego do Wacława Komara, b.m., 7 II 1949 r., 522, 523.

144 Ibid., [Stanisław Nowicki] Notatka w sprawie pieniędzy przerzucanych w drodze nieoficjalnej do Kraju z kierunku „Drawy”, b.m., 15 I 1949 r., 579-581.

145 Ibid., [Raport poufny Stanisława Nowickiego dla Wacława Komara], b.m., 15 XII 1948 r., 508, 509. Tam znajduje się wyjaśnienie genezy donosu nt. „szafek” z dolarami Tatara i Komitetu Trzech u różnych osób w Polsce. Generalnie Nowicki twierdził, że swoje „szafki” w porozumieniu i za wiedzą Komara - zlikwidował i dostarczył do centrali wywiadu 47845 dolarów; „zadbał” przy tym o interesy osób, które „szafki” przechowywały, prosząc Komara, ażeby nie wnikać w ich personalia - na co szef Oddziału II się zgodził. Jednak, gdy Komar zapytał, czy to oznacza, że w Polsce żadnych skrytek z dolarami już nie ma („nie ma zamiaru wkraczać, ani konfiskować tych pieniędzy, jednakże stanowczo żąda podania ich 
czesną postawę Nowickiego najlepiej oddają jego własne słowa: „W obecnej poczcie załączyłem notatkę z 15 I b. r. Przygotowując to opracowanie nie kierowałem się bynajmniej chęcią «sypania» kogoś, czy działania na czyjąś niekorzyść; widziałem jednak zainteresowanie Pana Generała tymi sprawami, to też po powrocie do Londynu zabrałem się do kompletowania dostępnych danych. Ostatnie wieści z Kraju przyspieszyły ich przekazanie. Nie mam podstaw do oceny wartości tych danych, gdyż większość nazwisk nie ma dla mnie żadnej wymowy. Możliwe, że naświetlone akcje były istotnie tylko stosunkowo nieszkodliwym trwonieniem publicznego pieniądza. Jeśli jednak w tym jest coś poważniejszego, jak np. «mobilizacja sił AK» nie sądzę, abym miał moralne prawo zachowania tych informacyj dla siebie [podkreślenie - D.K.]". ${ }^{146}$ Komentarz wydaje się zbędny - gorliwość neofity widoczna jest aż nadto. Wkrótce sprawa stała się znana organom bezpieczeństwa ${ }^{147}$ i w czasie śledztwa Tatar był wielokrotnie o to indagowany, a owe osoby - których nazwiska dla delatora nie miały „żadnej wymowy” - poniosły tego konsekwencje. Nowicki zdawał sobie sprawę, że notatka obciąża jego przełożonego - wbrew temu co napisał, że nie chce nikogo, czyli Tatara, „wsypać” - lecz domyślając się zainteresowania Komara tą sprawą, myślał, że kupuje sobie lepszą pozycję przetargową.

Nowicki raportował, że na pomysł wsparcia pieniędzmi z funduszu dolarowego byłych żołnierzy AK i członków ich rodzin wpadł Tatar już w 1945 r., choć ten ostatni w zeznaniu z 8 listopada 1949 r. twierdził, że sprawa została przyjęta formalnie do realizacji przez Komitet Trzech latem 1946 r. ${ }^{148}$ Wydaje się, że wersja Nowickiego była bliższa prawdy, a Tatar próbował rozłożyć odpowiedzialność na cały Komitet. We wspomnianym zeznaniu Tatar twierdził, że po podjęciu decyzji przez Komitet omówił sprawę z gen. dyw. Kopańskim i prof. Marianem Grzybowskim (kpt. lek., oficerem AK ps. „Bakcyl”, przyjacielem Kopańskiego sprzed lat). Pomysł sprowadzał się do powierzenia zaufanym ludziom $w$ kraju pewnych kwot $\mathrm{w}$ dolarach, które by zdeponowali w tzw. „szafkach”, z których z kolei wypłacaliby zapomogi zgłaszającym się po nie po wcześniejszym wylegitymowaniu się właściwym hasłem. Jak Tatar zeznał, ludzie przychodzący od niego musieli znać hasło „Kostka”; z kolei od Utnika

rozlokowania, gdyż władze w kraju muszą mieć świadomość istnienia w terenie zasobów waluty obcej”), to Nowicki „nie miał wyboru, tylko musiał uczynić zadość żądaniu szefa O. II” i podał stan „szafek” Tatara wynoszący wg niego 29875 dolarów.

146 Ibid., List Stanisława Nowickiego do Wacława Komara, b.m., 7 II 1949 r., 523.

147 Komar kilka dni później przekazał raport Nowickiego wiceministrowi bezpieczeństwa publicznego gen. bryg. Romanowi Romkowskiemu, zob. AIPN, MSW, 0192/760/24, cz. 2, Pismo Wacława Komara do gen. Romana Romkowskiego, nr 419/15/00103/49, b.m., 15 II 1949 r., 302 i n.

148 AIPN, SWSW, 2386/13880, Protokół przesłuchania Stanisława Tatara, Warszawa, 8 XI 1949 r., 26. 
musieli podać hasło „Maria”. ${ }^{149}$ Nowicki w wyżej wspomnianej notatce podał, że "szafek" było pięć - z tym, że wymienił tylko czterech ich depozytariuszy: prof. Grzybowskiego, kmdr. ppor. dr. Szczepana Wacka (lekarza Szpitala Wojskowego w Gdańsku-Oliwie, w czasie okupacji mjr. lek. AK ps. „Toruński”; Tatar znał go jeszcze sprzed wojny i z czasów okupacji), płk. dypl. Edwarda Maliszewskiego (artylerzystę, przyjaciela Tatara, którego znał z górą 25 lat, a w latach 1944-1945 był jego oficerem do zleceń, jako zastępcy szefa SNW ds. Krajowych) i mjr. Władysława Romana (podwładnego Tatara z 3 pal i z konspiracji, ps. „Krzesław”). „Szafki” miały zostać zlikwidowane przez Tatara pod naciskiem - głównie Nowickiego - w październiku 1948 r. ${ }^{150}$ Utnik w swoich zeznaniach z 4 listopada 1949 r. uzupełnił, że ostatnia z „szafek” znajdowała się pod opieką sióstr Tatara w Warszawie. Ponadto zeznał, że Grzybowski, Wacek i Maliszewski dysponowali w swoich „szafkach” każdy po 25 tys. dolarów, siostry Tatara posiadały 10 tys. dolarów, a Roman 9 tys. dolarów oraz to, że on mógł dysponować pieniędzmi tylko z „szafki” Maliszewskiego i Wacka, po podaniu hasła: „Maria”. ${ }^{151}$

Ponadto Tatar miał przerzucać do kraju pieniądze poprzez ppłk. Garlickiego ps. „Bogumił”, któremu dał 99 tys. dolarów w gotówce i 1 tys. dolarów w złocie. Garlicki złożył te pieniądze w depozycie w Luksemburgu (był to ten depozyt „Drawy”, który wiązał się z wcześniej omawianą sprawą konsula Sobolewskiego) i zbudował własną sieć kurierską do kraju, m.in. 21 stycznia 1946 r. wysłał z terenu Niemiec parę kurierów: byłego oficera AK por. Stefana Berenta ps. „Steba” i Janinę Konopacką z 10 tys. dolarów. Garlicki miał wysłać do kraju (oprócz misji Berenta i Konopackiej) 6780 dolarów papierowych i 60 dolarów w złocie (jako zapomogi bezzwrotne) oraz 3350 dolarów papierowych i 80 dolarów w złocie (jako zaliczki zwrotne lub należności odprawowe). Nowicki wspomniał także o dorywczych (okazyjnych) przerzutach pieniędzy do kraju (kwoty około 1-3 tys. dolarów), ale z funduszu dolarowego znajdującego się na terenie Niemiec, zanim został on przejęty przez kierownictwo PSZ (Nowicki określa go funduszem Kopańskiego, choć później stanowił on fundusz ppłk. dypl. Kamieńskiego ps. "Cozas”), co oznacza, że były to sprawy sprzed ponad dwóch lat. ${ }^{152}$

\footnotetext{
149 Ibid., 26, 27.

150 Ibid., 2306/13909/2, [Stanisław Nowicki] Notatka w sprawie pieniędzy przerzucanych w drodze nieoficjalnej do Kraju z kierunku „Drawy”, b.m., 15 I 1949 r., 579, 580. Nowicki nie wierzył jednak w szczerość deklaracji Tatara. Jego działania zmierzały z pełną stanowczością do maksymalnego podważenia wiarygodności przewodniczącego Komitetu Trzech i zapewne w konsekwencji do pozbawienia go wolności przez organa bezpieczeństwa.

151 Ibid., 2386/13890, Protokół przesłuchania Mariana Utnika, b.m., 4 XI 1949 r., 13.

152 Ibid., 2306/13909/2, [Stanisław Nowicki] Notatka w sprawie pieniędzy przerzucanych w drodze nieoficjalnej do Kraju z kierunku „Drawy”, b.m., 15 I 1949 r., 580, 581.
} 
O narastającej frustracji Tatara $\mathrm{w}$ ostatnich miesiącach przed aresztowaniem informują wyczerpująco raporty radcy ambasady w Londynie i informatora wywiadu Alberta Morskiego ps. „Dąbrowa”, który miał zadanie zdobyć zaufanie przewodniczącego Komitetu Trzech. Na pierwszym spotkaniu, podczas prywatnej kolacji 27 lipca 1949 r., po wypiciu znacznej ilości alkoholu Tatar otworzył się i m.in. uderzył werbalnie w gen. bryg. Gustawa Paszkiewicza, który będąc posłem na Sejm, publicznie go atakował; żalił się, że jest inwigilowany, że w Polsce aresztowano Plutę-Czechowskiego i jego brata Józefa. ${ }^{153}$ W kolejnym raporcie z 18 sierpnia 1949 r. „Dąbrowa” donosił o atakach Tatara na gen. dyw. Ignacego Modelskiego, o zaniepokojeniu zachowaniem Utnika, który wrócił z ostatniego wyjazdu do Warszawy speszony i szykował się być może do oderwania się od współpracy z komunistami i pozostania na emigracji, ${ }^{154}$ o libacjach Utnika wraz z Chojeckim z udziałem kobiet - przy czym Tatar określił Utnika mianem erotomana. ${ }^{155}$

W całej, blisko pięcioletniej, działalności Komitetu Trzech na gruncie emigracyjnym najbardziej zastanawiająca jest bierność, z jaką władze wywodzące się w prostej linii od legalnego rządu RP na uchodźstwie pogodziły się z utratą potężnych środków finansowych, niemalże milcząco akceptując ich wrogie przejęcie przez Tatara i jego wspólników. ${ }^{156}$ Dopiero 12 sierpnia 1949 r. Komisja Specjalna Rady Narodowej RP pod przewodnictwem Jerzego Kuncewicza (prezesa SL „Wolność”) - organ polskich władz emigracyjnych powołany dla zbadania i ustalenia podstaw finansowych oraz działalności gospodarczej władz państwowych od 1 lipca 1944 r. - wezwał Tatara

153 Ibid., [„Dąbrowa” - Albert Morski] Notatka z rozmowy z gen. Stanisławem Tatarem, b.m., 28 VII 1949 r., 551-553.

154 Powód zmieszania Utnika wynikał ze zmuszenia go przez Komara do podjęcia współpracy agenturalnej z Oddziałem II SG (został najprawdopodobniej zaszantażowany zeznaniami na rozprawie Doboszyńskiego) - „Dąbrowa” słusznie skonstatował, że Utnik może próbować urwać się komunistom, gdyż wg jego zeznań po powrocie do Londynu w czerwcu 1949 r. podjął działania zmierzające do nawiązania kontaktu z płk. Haroldem Perkinsem i ujawnienia się przed nim jako agent wywiadu komunistycznego, z prośbą o pomoc w wyjściu spod krępującej go kurateli; zob. AIPN, SWSW, 2386/13890, Protokół przesłuchania Mariana Utnika, Warszawa, 5 XI 1949 r., 19, 20.

155 Ibid., 2306/13909/2, [„Dąbrowa” - Albert Morski] Notatka w sprawie gen. Stanisława Tatara, Stanisława Nowickiego, Mariana Utnika, Maksymiliana Chojeckiego i firmy mjr. [dypl.] Antoniego Gaca, pośredniczącej w zakupach Mariana Utnika, b.m., 18 VIII 1949 r., 559-566.

156 Jak wiadomo, władze wojskowe przejęły dużą część „Drawy” i można odnieść wrażenie, że zawarły z Tatarem cichy układ o nieagresji na zasadzie status quo. Tatar jeszcze do $1948 \mathrm{r}$. podtrzymywał, taktycznie, kontakt z Kopańskim oraz Kwapińskim - być może mamiąc ich przekazaniem na działalność czynników rządowych i wojskowych dolarów ze swojej dyspozycji. To wydaje się była ta niewidzialna siła, która powstrzymywała instytucje legalnego Rządu RP na emigracji przed intensyfikacją nacisków na członków Komitetu w sprawie oddania funduszy rządowych. 
w Paryżu do złożenia wyjaśnień w sprawie funduszy publicznych powierzonych jego pieczy. Ponieważ Tatar się nie stawił na przesłuchanie, wezwanie ponowiono w Londynie 3 września 1949 r, wyznaczając mu termin na 12 września. ${ }^{157}$ Paradoksalnie lokal Rady Narodowej RP w Londynie znajdował się przy Cornwall Gardens 74, a więc około 150 metrów od domów kupionych przez Komitet Trzech, gdzie mieszkali m.in. Nowicki i Utnik, ten ostatni zresztą też otrzymał podobne wezwanie. Oczywiście żaden z wezwanych nie stawił się przed Komisją Specjalną - formalnie zakazał im tego Komar w piśmie z 10 września. ${ }^{158}$

Dalsze działania zmierzające $\mathrm{w}$ kierunku wyjaśnienia sprawy funduszy Tatara władze emigracyjne podjęły już w październiku 1949 r., gdy ówczesny szef MON rządu emigracyjnego gen. bryg. Roman Odzierzyński skierował do Rady Narodowej RP dwa obszerne pisma $\mathrm{z}$ wyjaśnieniem na temat działalności Tatara (z 3 i 25 października tr.). Działalność Komisji Specjalnej Rady Narodowej RP (Kuncewicz, gen. dyw. Marian Żegota-Januszajtis, ks. Jan Brandys i Bohdan Podoski) zamknął raport z 9 sierpnia 1950 r., zawierający podsumowanie wiedzy posiadanej przez polskie władze emigracyjne na temat losów funduszy po rządzie RP na uchodźstwie z lat 1945-1950. Pomimo wysiłków członkowie Komisji w sprawie „Drawy” ponieśli spektakularne fiasko: „Komisja Specjalna nie była w stanie ustalić, jakimi kwotami tego funduszu rozporządzali Tatar i Utnik w chwili, gdy wymawiali posłuszeństwo prawowitym władzom Rzplitej i oddawali się do dyspozycji władzy warszawskiej". ${ }^{159}$ Członkowie Komisji nie tylko nie znali skali rabunku, ale także w ogóle się nie orientowali w fakcie istnienia Komitetu Trzech. Konspiracja Tatara i jego towarzyszy budzi „podziw” wprost proporcjonalny do opieszałości i nieudolności władz emigracyjnych. ${ }^{160}$

Ostatnie miesiące działalności Komitetu Trzech przyniosły niespodziewaną zmianę układów pomiędzy jego członkami. W pierwszych tygodniach $1949 \mathrm{r}$. Tatar, dość niespodziewanie, pogodził się z Nowickim, oczywiście utrzymując to w tajemnicy - wspólnie planowali „rozprawę” z Utnikiem. Najprawdopodobniej doszło do tego w związku z tym, że Utnik uwiódł jedną z córek Nowickiego, o czym donosił w raporcie do Warszawy „Dąbrowa”. Fakt pojednania

157 AIPN, SWSW, 2306/13909/2, Pismo przewodniczącego Komisji Specjalnej Rady Narodowej RP [Jerzego Kuncewicza] do gen. Stanisława Tabora-Tatara, L. dz. 8/II/Sp/49, Londyn, 3 IX 1949 r., 588. Identyczne wezwanie, na ten sam dzień, otrzymał Utnik, zob. ibid., Pismo przewodniczącego Komisji Specjalnej Rady Narodowej RP [Jerzego Kuncewicza] do ppłk. Mariana Utnika, L.dz. 9/III/Sp/49, Londyn, 5 IX 1949 r., 593.

158 Ibid., Depesza szyfrowa Wacława Komara do Maksymiliana Chojeckiego, b.m., 10 IX 1949 r., 597.

159 Siemaszko, Działalność, 231, 232.

160 „Sprawozdanie komisji specjalnej Rady Narodowej R.P. z dotychczasowego wyniku jej prac," Zeszyty Historyczne 22, nr 2 (1972): 81-93. 
ujawnił w liście do płk. dypl. Maliszewskiego z 12 września 1949 r., ${ }^{161}$ który przejęła już bezpieka $\mathrm{w}$ ramach perlustracji jego korespondencji.

Inną, być może mniej istotną, sprawą było zwerbowanie Utnika przez Komara ${ }^{162} \mathrm{w}$ czasie jego ponad dwutygodniowego urlopu w Polsce w okresie od 1 do 17 czerwca 1949 r. ${ }^{163}$ Faktycznie były szef Oddziału VI od 1948 r. aktywnie współpracował z wywiadem komunistycznym i formalne przyjęcie w poczet agentury Oddziału II - posługiwał się pseudonimem „Sabina”164 - niewiele zmieniło w jego położeniu. Ot, być może tyle, że Komar uspokoił swojego nowego agenta, że zeznania mjr. Tadeusza Nowińskiego w czasie procesu Adama Doboszyńskiego, obciążające także jego, nie powinny go niepokoić: „idzie to po linii ustalonej między nami w czasie Waszego pobytu w kraju". ${ }^{165}$ Współpraca ta była krótka i, jak wiadomo, nie przyniosła Utnikowi ratunku przed aresztowaniem, długim i brutalnym śledztwem, procesem oraz wyrokiem.

W jednej z notatek, jakie powstały $\mathrm{w}$ organach bezpieczeństwa tuż przed wezwaniem do kraju i aresztowaniem Tatara, Utnika i Nowickiego - kolejno było to: 2, 3 i 4 listopada 1949 r. - autor (najprawdopodobniej Komar lub któryś z jego zastępców) zadał retoryczne pytania: „1. Dlaczego zespół ludzi, których nie można nazwać entuzjastami obecnej polskiej rzeczywistości, przekazał około 3500000 dolarów Rządowi R.P. [Polski Ludowej]? 2. Dlaczego Anglicy lub Amerykanie nie rozprawili się $\mathrm{Z}$ «zespołem Tatara», aby fundusze odebrać?”. ${ }^{166}$ Zupełnie nie jest zaskakujące, że te „wątpliwości” pojawiły się w momencie, gdy „Drawa” została przejęta ${ }^{167}$ i można było

161 AIPN, SWSW, 2306/13909/2, List Stanisława Tatara do Edwarda Maliszewskiego, odpis nr 6745, b.m., 12 IX 1949 r., 600.

162 Ibid., 2386/13890, Protokół przesłuchania Mariana Utnika, Warszawa, 7 XI 1949 r., 24, 25; zob. także CAW-WBH, O. VI SNW, II.52.362; w teczce tej znajduje się kilka raportów, które napisał Utnik dla Komara (ukryty pod ps. „Roman”), z okresu od lipca do września 1949 r.; w tych raportach Tatar był ukryty pod ps. „Teodor”.

163 AIPN, SWSW, 2306/13909/2, Depesza szyfrowa Maksymiliana Chojeckiego do Wacława Komara, b.m., 26 V 1949 r., 541; Depesza szyfrowa Wacława Komara do Maksymiliana Chojeckiego, b.m., 15 VI 1949 r., 543.

164 AIPN, Zarząd II SG, 2602/482, Kryptonimy, 80; [płk Stanisław Bielski, kpt. Jerzy Wolf] Instrukcja dla „Sabiny”, b.m., [1949 r.], 78, 79.

165 AIPN, SWSW, 2306/13909/2, Depesza szyfrowa Wacława Komara do Maksymiliana Chojeckiego, b.m., 15 VI 1949 r., 545.

166 AIPN, Zarząd II SG, 2602/472, [gen. Wacław Komar?] Notatka - dotyczy grupy: Tatar, Utnik, Nowicki i funduszów przez nich administrowanych, b.m., b.d. i nr kanc., 19.

167 Choć i w to zaczęto wątpić: „Możliwe jest przy tym, że sumy przekazane mogą posłużyć jako przykrywka do zachowania i zamelinowania większych kwot, z których «zespół» nie będzie się wyliczał" (zob. ibid.). 
rozpocząć kroki zmierzające w kierunku likwidacji jej dysponentów. Równie nie zaskakuje, że jednym z pierwszych „wątpiących” był Komar, ${ }^{168}$ który współpracę z Komitetem Trzech bezpośrednio nadzorował przez dwa i pół roku, a następnie jako pierwszy złożył na nich donos do kontrwywiadu. Wszystko zaczęło się i kończyło w centrali wywiadu wojskowego Polski Ludowej, ale dla tegoż wywiadu i jego szefostwa także pojawiły się czarne chmury na horyzoncie. W notatce przygotowanej przez wysokich rangą oficerów MBP czytamy: „Cały wysiłek Oddziału II-go szedł po linii wydobycia pieniędzy [...] a nie celem ich [tzn. Tatara, Utnika i Nowickiego - D. K.] rozpracowania. [...] Oddział II Szt. Gen. dookoła zespołu N.T.U., w przeciągu trzech lat, nie zwerbował na emigracji ani jednego człowieka [...]. Zresztą nie mógł tego uczynić jeśli weźmiemy pod uwagę fakt, że przedstawicielami Oddz. II byli płk. [Józef] Kuropieska i płk. [Maksymilian] Chojecki - przedwojenni oficerowie Wojska Polskiego, bardziej związani z zespołem T.N.U. [różna kolejność inicjałów w oryginale - D.K.]". ${ }^{169}$ Była to zapowiedź koncepcji „konia trojańskiego" i „wielkiego spisku” w armii oraz wstęp do karuzeli represji, która pochłonęła tak członków Komitetu Trzech, jak i ich mocodawców $\mathrm{z}$ wywiadu wojskowego.

Postawa Tatara i jego wspólników - nawet jeśli przy dużej dawce dobrej woli uwierzy się w patriotyczne pobudki, które miały nimi powodować $\mathrm{w}$ pierwszym rzędzie - zasługuje na ocenę zdecydowanie negatywną. Wystarczy tylko stwierdzić, że na obecnym etapie badań nie wiadomo, jak zostało skonsumowane gros środków „Drawy”170 - informacja z raportu Kutina dla Komara, że 100 tys. dolarów zostało jesienią 1947 r. przeznaczone na rzecz PPR, jest być może kluczową wskazówką. Polityczna naiwność i łatwowierność, z jaką przyjmowali zapewnienia przedstawicieli komunistycznych decydentów, czy też spożytkowanie pewnej - relatywnie niewielkiej w skali całości - puli środków na zakupy dla potrzeb kraju, nie może być usprawiedliwieniem dla: defraudacji pieniędzy publicznych, zdrady legalnych władz

168 Obok płk. Krzemienia z GZI oraz Romkowskiego, gen. Mieczysława Mietkowskiego i płk. Józefa Czaplickiego z MBP; zob. Jerzy Poksiński, „TUN”. Tatar - Utnik - Nowicki. Represje wobec oficerów Wojska Polskiego w latach 1949-1956 (Warszawa: Bellona, 1992), 106.

169 AIPN, SWSW, 2386/13888, [płk Józef Czaplicki, gen. Roman Romkowski] Notatka informacyjna w sprawie T.N.U., b.m., 13 X 1949 r., 21. Notatka został następnie przesłana na ręce wiceministra bezpieczeństwa publicznego gen. Romana Romkowskiego, zob. ibid., [płk Leon Andrzejewski] [Przesłanie notatki Dep. I i III o Stanisławie Tatarze i Marianie Utniku], b.m., 13 X 1949 r., 24.

170 O wiele bardziej na wyobraźnię historyków, publicystów, dziennikarzy czy też amatorów działała zawsze sprawa losów złota z FON niż dolarów z „Drawy”, a przecież były to sumy znacznie wyższe niż wartość całego skarbu FON. Wydaje się, że pokutuje w świadomości zbiorowej poczucie, że dolary przekazane do kraju zostały w całości wykorzystane do zakupów niezbędnych materiałów dla zrujnowanego po wojnie kraju. Niestety stwierdzenie takie nie znalazło dotąd pokrycia w dokumentach. 
Rzeczpospolitej, którym składali przysięgę wojskową, oddania tajnych dokumentów armii, wywiadu, Oddziału Specjalnego i AK oraz współpracy agenturalnej (to odnosi się do Nowickiego i Utnika) w działaniach organów bezpieczeństwa skierowanych przeciwko swoim byłym kolegom i podkomendnym. Ich postawa moralna budziła nawet zdziwienie wśród towarzyszy $\mathrm{z}$ bezpieczeństwa: „W trakcie 3 letnich pertraktacji [...] ujawniono prawdziwe lub pozorowane niesnaski w zespole T.N.U. i wzajemne «sypanie się». Był okres, kiedy Nowicki i Utnik występowali wobec Oddz. II Szt. Gen. przeciwko Tatarowi”, ${ }^{171}$ a tylko dzięki aresztowaniu całej trójki nie doczekano się sytuacji odwrotnej, gdy Tatar z Nowickim wystąpiliby przeciwko Utnikowi.

Ponurym zrządzeniem opatrzności było, że cała trójka zasiadła na ławie oskarżonych, po brutalnym i długim śledztwie, za zbrodnie, których nie popełnili, ale za to nigdy nie rozliczono występków, które naprawdę obciążały ich sumienie i kwalifikowały się do uczciwego śledztwa i obiektywnej rozprawy sądowej.

\section{Bibliografia}

\section{Archiwalia}

Archiwum Instytutu Pamięci Narodowej w Warszawie

Akta Personalne Funkcjonariuszy Służby Bezpieczeństwa

Kartoteka Ogolnoinformacyjna

Ministerstwo Bezpieczeństwa Publicznego

Ministerstwo Spraw Wewnętrznych

Szefostwo Wojskowej Służby Wewnętrznej w Warszawie

Teczki Akt Personalnych

Zarząd II Sztabu Generalnego Wojska Polskiego w Warszawie

Archiwum Instytutu Polskiego i Muzeum gen. Sikorskiego w Londynie

Kolekcja Franciszka Demela

Centralne Archiwum Wojskowe Wojskowego Biura Historycznego

Kolekcja Teczek Akt Personalnych

Oddział VI Sztabu Naczelnego Wodza

\section{Źródła drukowane i wspomnienia}

„Sprawozdanie komisji specjalnej Rady Narodowej R.P. z dotychczasowego wyniku jej prac." Zeszyty Historyczne 22, nr 2 (1972): 81-93.

Zabiełło, Stanisław. Na posterunku we Francji. Warszawa: Wyd. Pax, 1967.

\section{Publikatory}

Monitor Polski 1947, nr 14, poz. 33.

171 AIPN, SWSW, 2386/13888, [płk Józef Czaplicki, gen. Roman Romkowski] Notatka informacyjna w sprawie T.N.U., b.m., 13 X 1949 r., 21. 


\section{Opracowania i artykuły}

Bagieński, Witold. Wywiad cywilny Polski Ludowej w latach 1945-1961. T. 2. Warszawa: Wyd. Instytutu Pamięci Narodowej, 2017.

Cenckiewicz, Sławomir. Długie ramię Moskwy. Wywiad wojskowy Polski Ludowej 1943-1991. Poznań: Wyd. Zysk i S-ka, 2011.

Koreś, Daniel. „Zanim wybuchła afera TUN. Generał Stanisław Tatar, Komitet Trzech, fundusz "Drawa» i operacja "Brzoza» 1944-1947." Pamięć $i$ Sprawiedliwość, nr 2 (36) (2020): 409-435, https://doi.org/10.48261/PIS203622.

Paczkowski, Andrzej. „W pogoni za złotem, czyli operacja TUN.” Studia Polityczne 37, nr 1 (2015): 65-91.

Pietrzak, Jacek. „Polscy uczestnicy hiszpańskiej wojny domowej.” Acta Universitatis Lodziensis. Folia Historica 97, (2016): 65-86, https://doi.org/10.18778/02086050.97.04.

Poksiński, Jerzy. „TUN”. Tatar - Utnik - Nowicki. Represje wobec oficerów Wojska Polskiego w latach 1949-1956. Warszawa: Bellona, 1992.

Siemaszko, Zbigniew Sebastian. Działalność generała Tatara 1943-1949. Lublin: Norbertinum, 2004.

Spałek, Robert. Komuniści przeciwko komunistom. Poszukiwania wroga wewnętrznego w kierownictwie partii komunistycznej w Polsce w latach 1948-1956. Warszawa: Wyd. Instytutu Pamięci Narodowej i Wyd. Zysk i S-ka, 2014.

\section{Opracowania niepublikowane:}

Soporowska-Wojtczak, Olga. „Twórczość Elżbiety Szemplińskiej-Sobolewskiej.” Dysertacja doktorska. Uniwersytet Adama Mickiewicza, Poznań, 2013.

\section{STRESZCZENIE}

\section{Daniel Koreś, U źródeł afery TUN. Generał Stanisław Tatar, rozpad Komitetu Trzech i przekazanie komunistycznemu wywiadowi wojskowemu funduszu „Drawa” 1947-1949}

W końcu maja 1947 r. gen. bryg. Stanisław Tatar i jego wspólnicy - płk dypl. Stanisław Nowicki oraz ppłk dypl. Marian Utnik - zdecydowali się jawnie na współpracę z komunistycznym wywiadem wojskowym. Kontakty z szefem sztabu Misji Wojskowej rządu warszawskiego (następnie attaché wojskowym w Londynie) płk. dypl. Józefem Kuropieską podjęli już w 1945 r. Następne dwa lata poświęcili na przekonanie komunistycznych włodarzy Polski, przez kanał wywiadu wojskowego kierowanego przez gen. bryg. Wacława Komara, że są atrakcyjnym partnerem do współpracy. Pod płaszczykiem szczytnych celów, za zdefraudowane pieniądze znajdujące się w dyspozycji Sztabu Naczelnego Wodza Polskich Sił Zbrojnych, które ukryli w tzw. funduszu „Drawa” oraz za złoto z Funduszu Obrony Narodowej, należące do polskiego rządu na emigracji, kupowali sobie faktycznie lepszą przyszłość w Polsce Ludowej. Tak przynajmniej sądzili, gdyż nieodległa przyszłość brutalnie zweryfikowała ich przypuszczenia. Niniejsza synteza działalności członków samozwańczego Komitetu Trzech z lat 1947-1949 - do momentu ich aresztowania przez 
komunistyczną służbę bezpieczeństwa - jest zapisem nie tylko upadku moralnego trzech wysokich stopniem i stanowiskiem oficerów Wojska Polskiego i Polskich Sił Zbrojnych, lecz także o wiele bardziej bolesnym studium ich wzajemnego delatorstwa na rzecz Oddziału II Sztabu Generalnego ludowego Wojska Polskiego.

Słowa kluczowe: afera TUN, Stanisław Tatar, Marian Utnik, Stanisław Nowicki, Wacław Komar, Drawa, Polskie Siły Zbrojne na Zachodzie, ludowe Wojsko Polskie

\section{SUMMARY}

\section{Daniel Koreś, At the Source of the TUN Scandal - General Stanisław Tatar, the Dissolution of the Committee of Three and the Transfer of the „Drawa" Fund to the communist Military Intelligence Services}

(1947-1949)

Towards the end of May 1947, Brig. Gen. Stanisław Tatar and his associates Col. Dipl. Stanisław Nowicki and Lt. Col. Dipl. Marian Utnik - openly decided to cooperate with the communist military intelligence services. Contact with Col. Józef Kuropieska, the Chief of Staff of the Warsaw government's Military Mission, began in 1945 when Kuropieska was a military attaché stationed in London. The next two years were devoted to persuading the communist authorities of Poland, through the military intelligence channel headed by Brig. Gen. Wacław Komar, that they were attractive partners with regards to cooperation. Under the guise of noble goals, they fraudulently transferred vast amounts of cash and gold (which represented the treasury of the National Defense Fund and belonged to the Polish Government in Exile) that was held in the so-called "Drawa” fund to the new communist regime in Warsaw. In doing so they thought they could buy themselves a better future in Poland, however their assumptions were soon to be brutally curtailed. This synthesis of the activities of the self-proclaimed Committee of Three from 1947-1949 - until their arrest by the communist security service - represents not only the moral decline of three high ranking Polish Army officers and the Polish Armed Forces, but also a much more painful study of their mutual deliberations for the benefit of II Department of the General Staff of the Polish People's Army.

Keywords: TUN affair, Stanisław Tatar, Marian Utnik, Stanisław Nowicki, Waclaw Komar, Drawa, Polish Armed Forces in the West, Polish People's Army

\section{АННОТАЦИЯ}

Даниэль Коресь, У источников аферы ТУН. Генерал Станислав Татар, роспуск Комитета Трех и передача фонда „Драва” коммунистической военной разведке в 1947-1949 гг.

В конце мая 1947 года бригадный генерал Станислав Татар и его соратники - полковник дипл. Станислав Новицкий и подполковник дипл. 
Мариан Утник - открыто решили сотрудничать с коммунистической военной разведкой. Контактировать с начальником штаба Военной миссии варшавского правительства (впоследствии военным атташе в Лондоне), полковником дипл. Юзефом Куропеской, они начали уже в 1945 году. Следующие два года были посвящены убеждению коммунистических властей Польши через канал военной разведки, возглавляемый бригадным генералом Вацлавом Комаром, что они являются привлекательным партнером для сотрудничества. Под прикрытием благородных целей, за деньги, находящиеся в распоряжении штаба Верховного главнокомандующего Польскими вооруженными силами, которые они спрятали в т. н. фонде „Драва”, а также за золото из Фонда национальной обороны, принадлежащего польскому правительству визгнании, они фактически купили себе лучшее будущее в Польской Народной Республике. По крайней мере, они так думали, потому что ближайшее будущее жестоким образом проверило их предположения. Этот синтез деятельности членов самопровозглашенного Комитета Трех в 1947-1949 гг. - до их ареста коммунистической службой безопасности свидетельствует не только о моральном упадке трех высокопоставленных чиновников польской армии и польских вооруженных сил, но также и о гораздо более болезненном явлении их взаимных обвинений в интересах II Отряда Генерального штаба народного Войска Польского.

Ключевые слова: афера ТУН, Станислав Татар, Мариан Утник, Станислав Новицки, Вацлав Комар, Драва, Польские вооруженные силы на западе, народное Войско Польское 